\title{
An Archaeological and Historical Program for Data Recovery Along Houston and Bowie Streets, San Antonio, Texas
}

\author{
A. Joachim McGraw \\ John W. Clark Jr.
}

Follow this and additional works at: https://scholarworks.sfasu.edu/ita

Part of the American Material Culture Commons, Archaeological Anthropology Commons, Environmental Studies Commons, Other American Studies Commons, Other Arts and Humanities Commons, Other History of Art, Architecture, and Archaeology Commons, and the United States History Commons

Tell us how this article helped you.

This Article is brought to you for free and open access by the Center for Regional Heritage Research at SFA ScholarWorks. It has been accepted for inclusion in Index of Texas Archaeology: Open Access Gray Literature from the Lone Star State by an authorized editor of SFA ScholarWorks. For more information, please contact cdsscholarworks@sfasu.edu. 


\section{An Archaeological and Historical Program for Data Recovery Along Houston and Bowie Streets, San Antonio, Texas}

\section{Licensing Statement}

This is a work produced for the Texas Department of Transportation (TxDOT) by the report producer. TxDOT and the report producer jointly own all rights, title, and interest in and to all intellectual property developed under TXDOT's contract with the report producer. The report may be cited and brief passages from this publication may be reproduced without permission provided that credit is given to both TXDOT and the report producer. Permission to reprint an entire chapter, section, figures or tables must be obtained in advance from either the Supervisor of the Archeological Studies Branch, Environmental Affairs Division, Texas Department of Transportation, 125 East 11th Street, Austin, Texas, 78701 or from the report producer. 
AN ARCHAEOLOGICAL AND HISTORICAL PROGRAM FOR DATA RECOVERY ALONG HOUSTON AND BOWIE STREETS, SAN ANTIONO, TEXAS

A. Joachim McGraw

with contributions by John W. Clark, Jr.

Submitted to the National Advisory Council for Historic Preservation Denver, Colorado

Texas

State Department of Highways and Public Transportation

Highway Design Division

May, 1987 


\section{CONTENTS}

List of Figures. . . . . . . . . . . . . . . . . . . 3

List of Tables . . . . . . . . . . . . . . . . . 5

Introduction . . . . . . . . . . . . . . . . . 6

Description of Street Modifications. . . . . . . . . . . 7

Archaeological-Historical Background of Study Area . . . . . . . 9

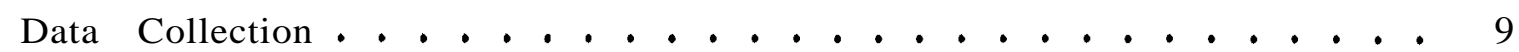

Historical Summary (Spanish Colonial Period - ca. 1840). . . . - 11

Historical Summary (CAR-USTA continuation) . • . . . . . . . 21

Previous Investigations Within the Las Tiendas Mall Area . . . . 23

Limited Testing Operations . . . . . . . . . . . . . . . 30

Testing Strategy . . . . . . . . . . . . . . 30

Summary of Archaeological Testing. . . . . . . . . . . . 32

Introduction . . . . . . . . . . . . . . . . 32

Field Methodology. . . . . . . . . . . . . . . 34

Lots 23 and 24 . . . . . . . . . . . . . . . . . . . .

Lots A25, 25 . . . . . . . . . . . . . . . . . 4 46

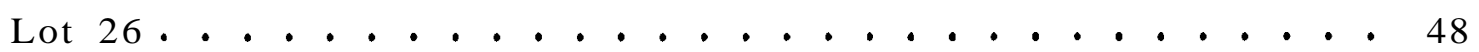

Lots A27, B27..................... . 48

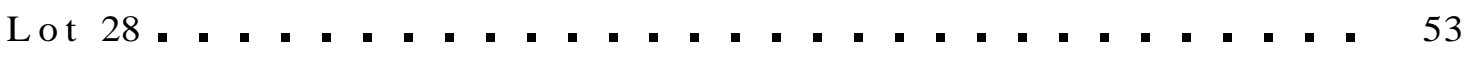

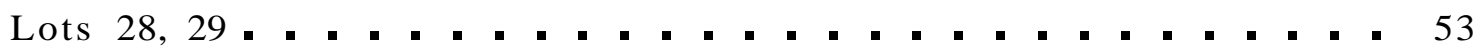

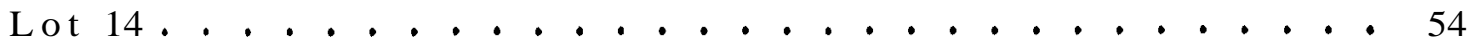

Lots 12,13 . . . . . . . . . . . . . . . . . . . 55 


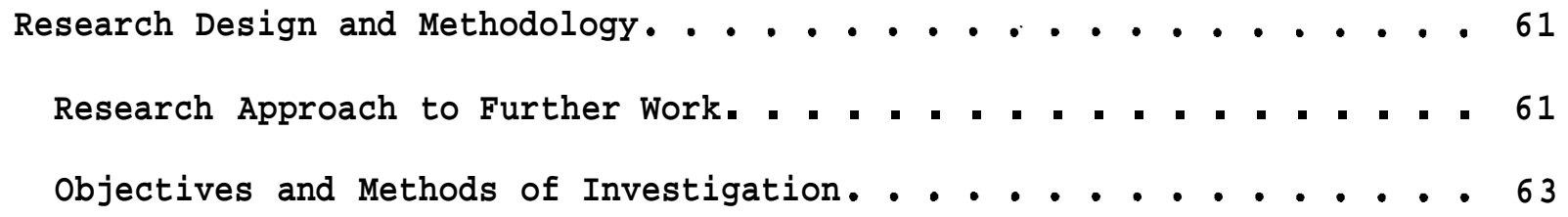

Recommendations for Further Work . . . . . . . . . . . . . . . 67 Lot-Specific Recommendations . . . . . . . . . . . . . . . . 67

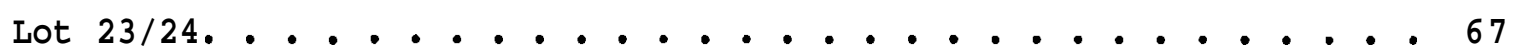

Lot A25. . . . . . . . . . . . . . . . . . . . . 67

Lot 29 . . . . . . . . . . . . . . . . . . . . . . 68

Lot 14 . . . . . . . . . . . . . . . . . . . . . . 68

Lot 12/13. . . . . . . . . . . . . . . . . . . . . 68

Additional General Recommendations/Project Considerations. . . . . . 69

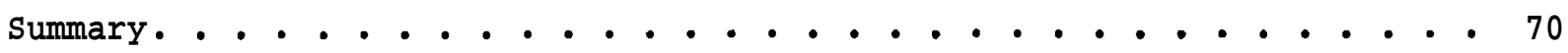

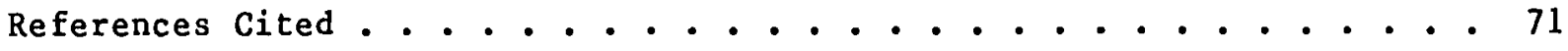

References Consulted . . . . . . . . . . . . . . . . . . . . 73 


\section{LIST OF FIGURES}

Figure 1 Limits of Project Area . . . . . . . . . . . 8

Figure 2. Earliest Sketch of Study Area. . . . . . . . . . 12

Figure 3 Mapa Del Presidio De San Antonio De Bexar . . . . . . 13

Figure 4 Lebastida's Map of the Alamo, 1836. . . . . . . . 15

Figure 51912 San Antonio Street Map with Original Suerte Ownerships . . . . . . . . . . . . . 16

Figure 6 Rullman's Map of San Antonio. 1837. . . . . . . . . 18

Figure 7 Jose Juan Sanchez Navarro's Map of the Alamo. 1836. . . 20

Figure $8 \quad$ Vicinity of Commerce Street and Bonham or Bowie. . . . 22

Figure 9 Vicinity of Crockett and Bonham Streets. . . . . . . 23

Figure 10 Koch's Map of San Antonio, 1873. . . . . . . . . . 24

Figure 11 UISA-CAR Archaeological Investigation to Date a t Las Tiendas Mall Area . . . . . . . . . . 27

Figure 12 Project Divisions for Cultural Resources Evaluation. . . 30

Figure 13 New City Block 165 Along Houston and Bowie Streets . . 33

Figure 14 Plan Map of Testing Operations. Lots 23/24 . . . . . . 38

Figure 15 Close-Up of Rock Rubble Foundation ca. 1840-1850

Exposed in Lot 23. . . . . . . . . . . . 39

Figure 16 Overview of Wall/Foundations in Lot $23 \quad$. . . . . . . . 39

Figure 17 Close-up of Concrete Pier Excavated in Lot 24. • . . . 41

Figure 18 Mapping of Early 20th Century Concrete Foundation Piers From Commercial Structure in Lot 24. . . . . . . . 41

Figure 19 Sanborn Map. 1885. . . . . . . . . . . . . 43

Figure 20 Sanborn Map. 1904. . . . . . . . . . . . . . . 44

Figure 21 Sanborn Map. 1912. . . . . . . . . . . . . . 45 
Figure 22 Walkway (?) of Large Limestone Blocks Uncovered in

Lot A25. . . . . . . . . . . . . . . . . . . . 49

Figure 23 Side View of Limestone Blocks. . . . . . . . . . . . 49

Figure 24 Extract of 1870 Census. San Antonio. . . . . . . . 52

Figure 25 Extract of Field Surveyor's Notes for Study Area . . . . 56

Figure 26 Plan Map of Testing Operations. Lots 23/24, . . . . 58

Figure $27 \quad$ View of Hand and Mechanical Testing in Lots 12 and 13.

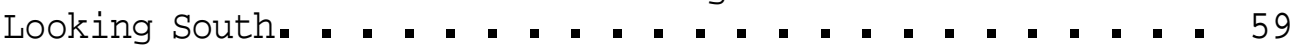

Figure 28 Former Basement of Karges Building . . . . . . . . 59 


\section{LIST OF TABLES}

Table 1 Summary of Excavation Data. Lot 23 . . . . . . . . 37

Table 2 Summary of Excavation Data. Lot 24. NCB 165. . . . . . 40

Table 3 Summary of Excavation Data. Lots A25, 25. NCB 165. . . . 47 
This report presents a program for archaeological and historical data recovery along portions of Houston and Bowie Streets, San Antonio, Texas. These streets, situated just east of the Alamo Plaza Historic District, are scheduled for expansion as parts of main access routes to the inner-city Las Tiendas Mall development in San Antonio. Both the mall complex and street expansion have projected completion dates of December 1987.

A brief discussion of the street modifications, the archaeological and historical significance of the study area, and preliminary investigations are presented as an introduction to a description of limited testing. Based on past field work and archival reviews, recommendations for further work are presented with particular emphasis on research design, strategy, and methodologies.

All field work to date and portions of the background historical research have been conducted by the Archaeology Office, Community Factors Section, Highway Design Division, Texas State Department of Highways and Public Transportation (SDHPT), Austin. In cooperation with the SDHPT and Day-Zimmermann, Inc. (consulting managers of the Las Tiendas Project), the Center for Archaeological Research, the University of Texas at San Antonio (CAR-UTSA) has also furnished a preliminary archival review for the project area. Extracts from these data are included in section II-Bof this report. 


\section{Description of Street Modifications}

\section{(Extracted From SDHPT Project Description)}

The project limits for this San Antonio urban systems improvement on Houston and Bowie Streets are Bonham and Commerce streets, major city arterial facilities (Figure 1). They are also the logical study termini. The character of the area is urban. Project length along the new and existing alignment is 1585'. The existing right-of-way width is usually 44.4'. The proposed width varies from 72' on Houston Street to 86' on Bowie between Houston and Crockett and 81' between Crockett and Commerce. Access control is limited only by city regulations and topography. This will remain unchanged. The type of facility planned utilizes a curbed boulevard section on both Houston and Bowie Streets. Houston Street will have four lanes with a 12' raised median. The two outside lanes will be 13' wide and the two inside ones, 11'. Bowie Street, between Houston and Crockett Streets, will have five lanes separated by a 12' raised median. Three southbound lanes will be $12^{\prime}$ wide except for the outside lane which will be 13'. The two northbound lanes will be $12^{\prime}$ for the lane near the median and 13' on the outside one. Between Crockett Street and Commerce Street there will be two northbound lanes, three southbound lanes and a $12^{\prime}$ wide raised median. The outside lanes on both will be $12^{\prime}$ wide, the other 11'. The general horizontal and vertical alignment is very moderate and typical of a southwestern urban setting. There are no interchanges, bridges or other structures planned. At-grade intersections will be at E. Commerce, Blum, Crockett, Houston and Bonham streets. The current and design average daily traffic are 3700 vehicles per day and 7500 vpd respectively. The nature of service these streets will perform is that of urban arterials. Utility 


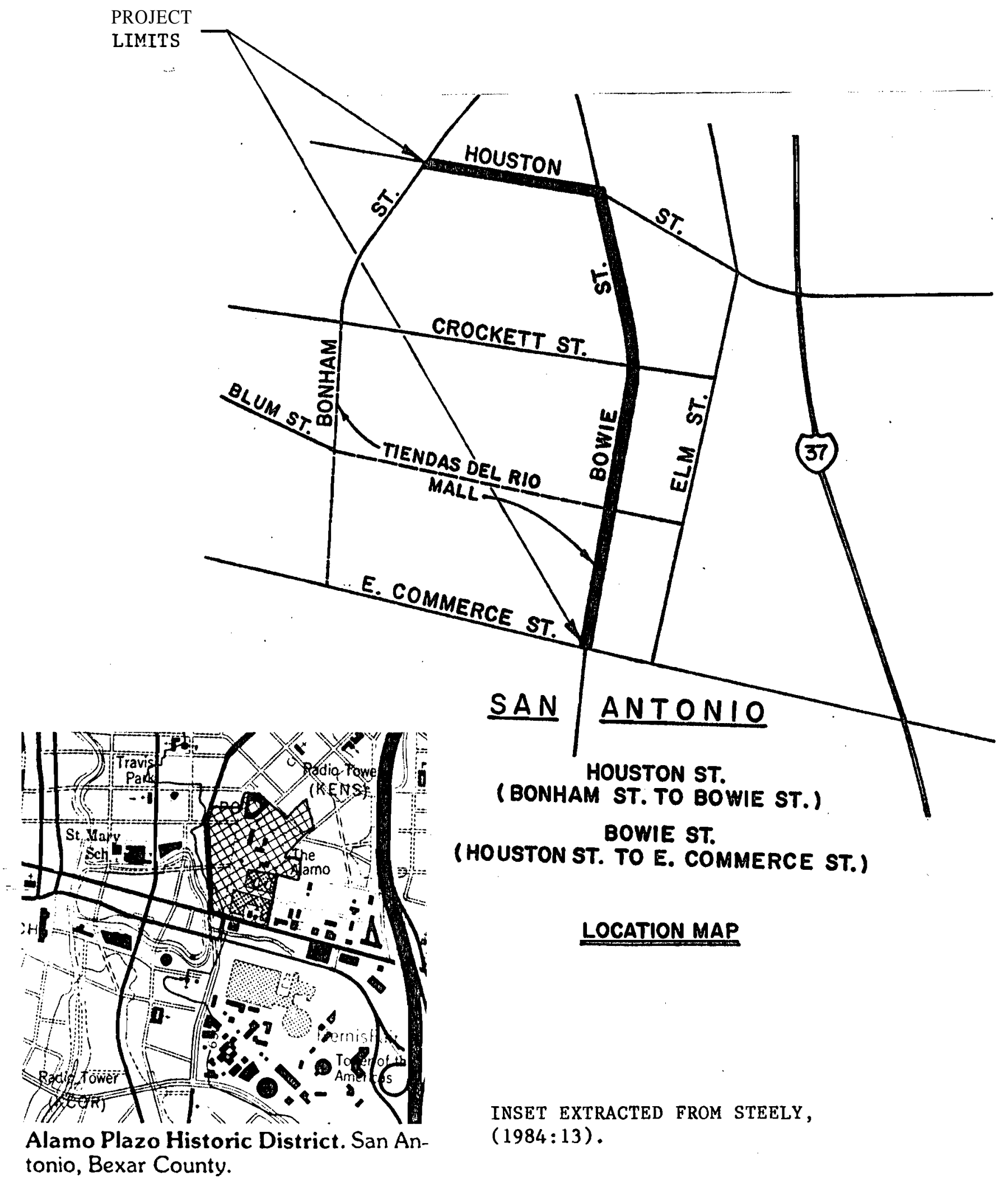

Figure 1. Limits of the Project Area 
adjustments are contemplated as this project is an integral part of the Tiendas Del Rio Downtown Mall project.

\section{Archaeological-Historical Background of Study Area}

\section{$\underline{\text { Data Collection }}$}

The archaeological and historical resources in the immediate vicinity of the Houston-Bowie Streets project area fall into two broad categories: (1) those cultural remains which may be linked to supportive historical documentation and; (2) cultural remains -- either prehistoric or historical -- for which no documentary record ever existed, for which such records have been destroyed in past times, or for which no records have yet been found. These historical categories may be subdivided by seven broad chronological periods that are associated with the area's development: (1) the Historic Indian and Spanish

Colonial period; (2) Secularization and Early Mexican; (3) Texas Republic and Annexation; (4) Mid-Late 19th century (from early statehood to Civil War); (5) Reconstruction; (6) Late 19th-early 20th century residential and; (7) 20 th century commercial.

The SDHPT's historical/archaeological review was originally directed toward a collection of data that would not only present an overview to the historical development of the area but would also include a block and lot specific description of former property ownerships and past structures along HoustonBowie Streets. This information would be considered in the light of previous archaeological and historical work in the area, past destructive impacts, and the potential for significant cultural resources in the impacted locales. 
During the preliminary overview study, it was learned that Day-Zimmermann, Inc., consulting managers of the Las Tiendas Project, had contacted UTSA and asked the CAR-UTSA to conduct a preliminary archival review along portions of the Houston-Bowie Streets project. This was initiated to expedite any further work and to cooperate as closely as possible with any SDHPT involvement.

The brief UISA report, produced by I. Waynne Cox a short time later, was a records review (from the 1850's - modern times) from the Bexar County Courthouse. Cox concentrated on the past ownerships and recorded structures along East Houston Street between Crockett and Bonham Streets. The Cox report was reviewed by archaeologists of the SDHPT as part of the CAR-UTSA Las Tiendas Project source materials and extracts have been included in descriptions of the historical background of specific lots.

The archival review conducted by A. McGraw, SDHPT archaeologist, then concentrated on data collection and assessments of cultural resources potential prior to the mid-19th century. Sources consulted for this latter work include information on file at the following sources:

Austin:

The Barker Texas History Center

The Latin American Studies Center

The (PCL) Casteneda Library

The Catholic Archives of Texas

The Texas Natural Resources Information Service data on file, Archaeology Library, SDHPT

San Antonio:

data on file, City Historic Preservation Office Research Library, Daughters of the Republic of Texas, The Alamo

Spanish Archives, Bexar County Courthouse Records Old Spanish Mission Records, Our Lady of the Lake University

Center for Archaeological Research, The University of Texas at San Antonio 
In addition to background archival collection, coordination was also established by the Environmental and Community Factors Section, Highway Design Division, SDHPT, with the principal parties directly or indirectly involved with different aspects of the street modification project.

$\underline{\text { Historical Summary }}$

This brief review is divided into two segments. The first, compiled by A. McGraw of the SDHPT, discusses developments from the Spanish Colonial period to ca. 1840. The data focus on the Mission San Antonio de Valero and its mission fields east of the compound, the impacts of secularization, and later aspects of the area as part of the 1836 battlefield. The area of discussion actually covers a much wider location than the current Houston-Bowie Streets locale but the SDHPT road project is an integral part of this larger area.

The lack of detailed historical records throughout these time frames, by nature, makes such an overview general in scope but nonetheless offers a broader perspective from which to postulate the evidences of early archaeological remains.

Throughout the mission period of San Antonio de Valero, the lands east of the mission compound were utilized for cultivation. The general area is illustrated in Figures 2 and 3. The crops from these fields included maize, chili, beans, and cotton, as described in 1762 by Fray Mariano Francisco de I OS Dolores during an inspection of the mission. Fray Mariano also noted that (at least some) of these fields were fenced (in Schuetz 1966: 24, 26). These 


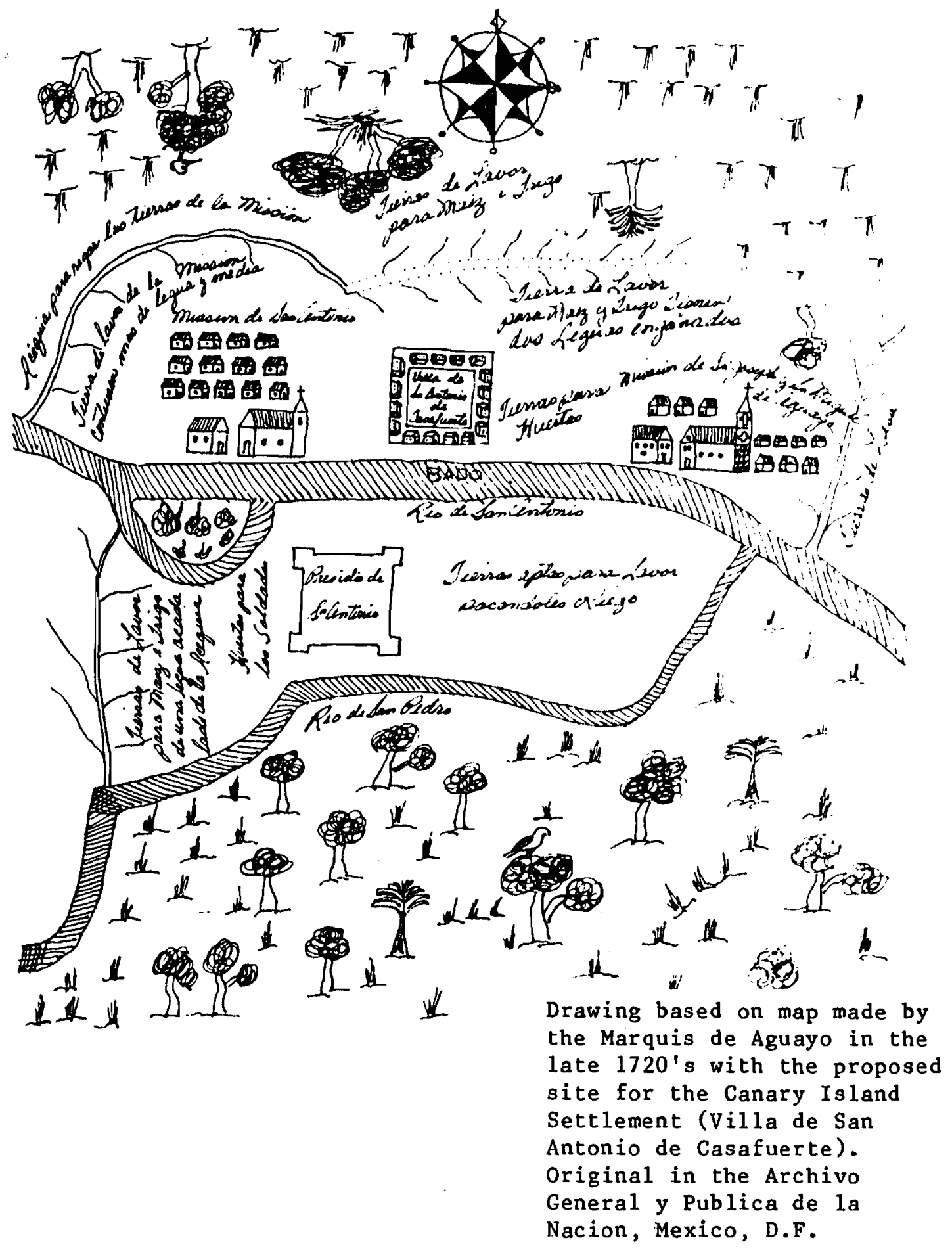

Figure 2. Earliest sketch found for area. Extracted from Schuetz, 1966. 


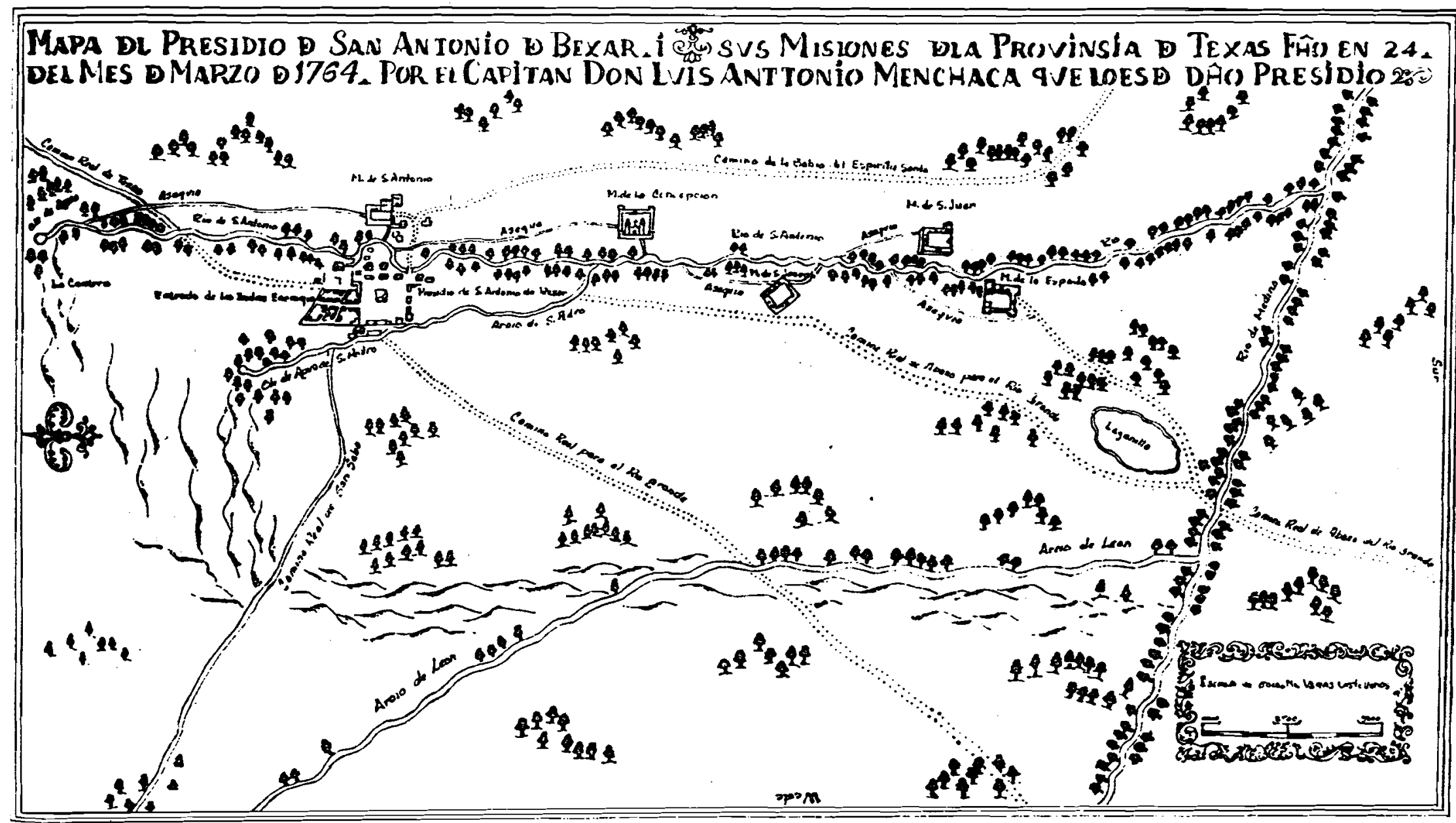

Fig. 3 Mapa del Presidio D San Antonio D Bexar. Drawing from Menchaca, 1764. Extracted from Schuetz, 1966. 
fields were irrigated by the Acequia Madre (located ca. one block east of present-day Bowie Street). Some indications of lateral canals are illustrated on a drawing based on a map by the Marquis de Aguayo in the late 1700's and portions of the fields are in the background of the Labastida map of the Alamo in 1836 (see Figure 4). By 1777-1778, Morfi noted the mission population was so reduced, it barely had enough people to cultivate the fields (Castaneda, 1932:81-82).

No references to jacal or other structures constructed outside and east of the complex walls have been uncovered for the Spanish Colonial/Mission Period. It should be noted that this negative evidence is the result of a lack of documentary data, not necessarily, actual fact. In conversation with James Ivey, National Park Service archaeologist, Southwest Region, it was recently pointed out that a previously undocumented colonial lime kiln may have existed in the area of the Acequia Madre east of the mission (vicinity of or east of presentday Bowie Street)(personal communication, 2/18/87).

Following a lengthy decline, the secularization of Mission San Antonio de Valero divided the mission lands among the 40 refugees from Los Adaes and to other Yalero mission peoples. Early records indicate that four and possibly five individuals drawing by lots took possession of the lands that encompass present-day Houston-Bowie Streets. These names are presented in the translations of the secularization document of 1793 (on file, Spanish Archives, Bexar County courthouse). The properties of the distribution are illustrated in the accompanying figure as they are overlaid on a 1912 San Antonio street map (Figure 5). It should be noted that these early suerte divisions may indicate the most likely locations for lateral irrigation canals of the Acequia Madre, a short distance to the east. There are some discrepancies in 


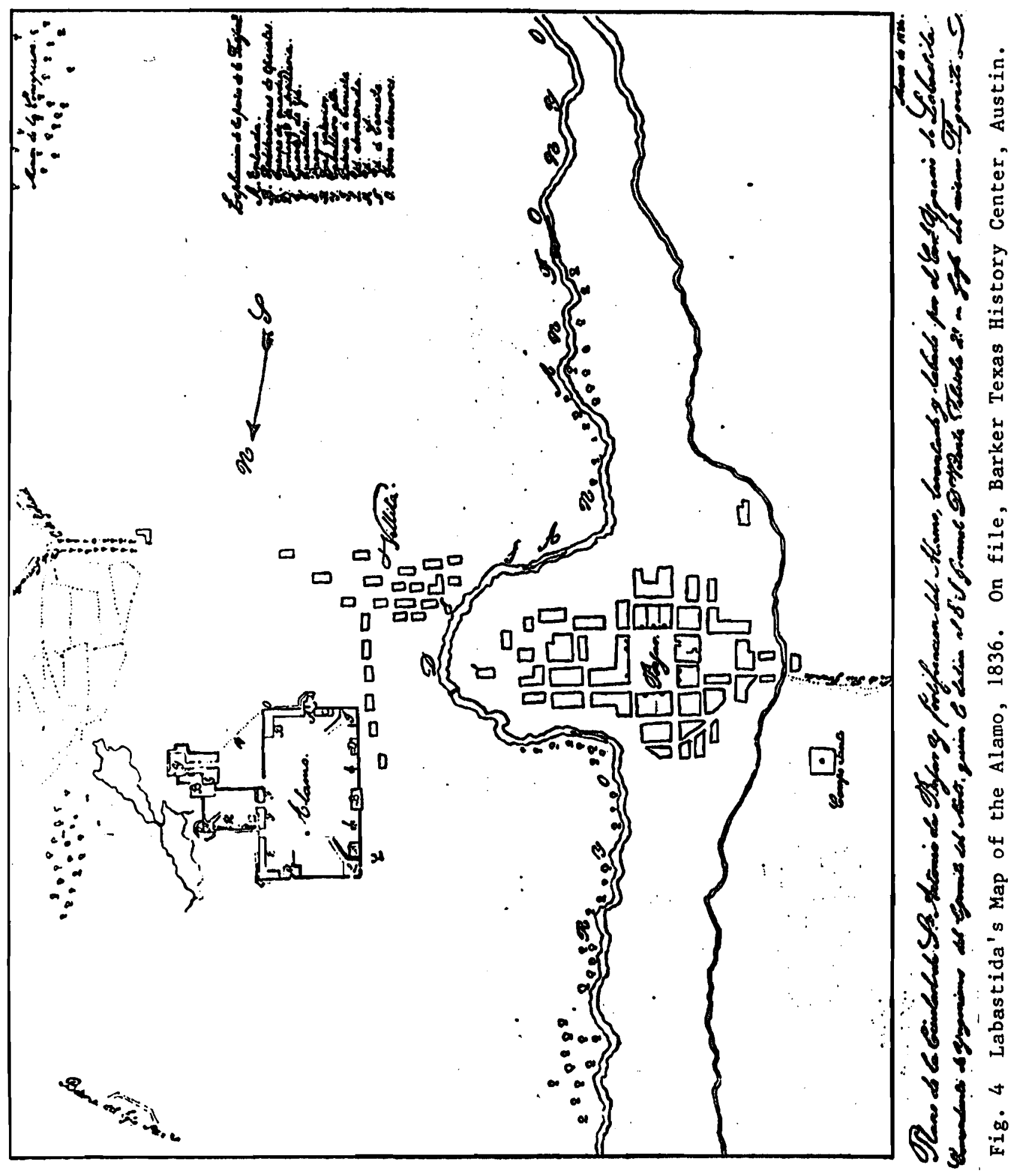




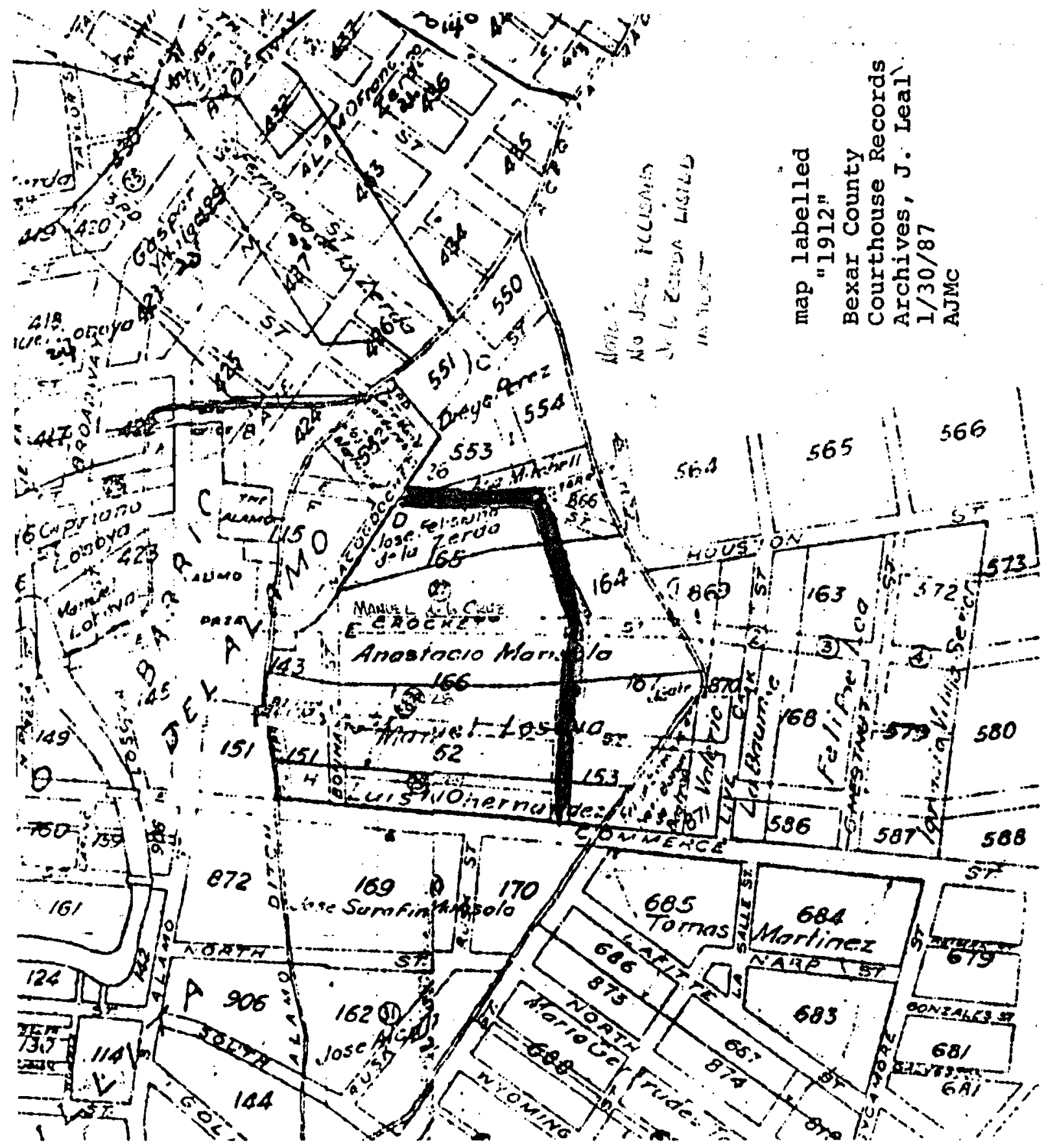

Fig. 51912 San Antonio street map with original suerte ownerships. Numbers in circles correspond (?) to original suerte numbers. On file, Bexar County Courthouse Archives. Note: no Jose de la Zerda listed, presumably Juan de la Zerda. Alternatively, it may refer to Jose de Zepeda of suerte \#26; this would then correspond with the sequence of names and numbers of the 1793 secularization land distribution. 
the preliminary archival documentation of these suertes; for example the sequence of names and suerte numbers listed in 1793 does not totally follow the accompanying 1912 map sequence or the Rullmann map of 1837 (Figure 6) identifying the same area.

The impact of secularization on the historical development of the current project area is illustrated by the report of the lieutenant governor of Valero in 1809. He reported that many cultivated fields had been abandoned for as long as 12 years due to the indifference of their owners and a decline of productivity following the land distribution of 1793 (in Schuetz 1966:35).

The lack of economic growth and the development of the city in general was critically affected by the destructive impacts of the Spanish General Arredondo's suppression of a provincial revolt in 1813. His actions, combined with regional Indian depredations, effectively arrested growth throughout the area for almost a decade. It Was only during the 1836 period of independence that the mission lands of San Antonio de Valero became historically significant as the battleground for the second (and more famous) battle of the Alamo that culminated on March 6, 1836.

General Miguel Sanchez noted (map on file, Barker Texas History center) that the Mexican cavalry under General Sesma occupied the Alameda (along presentday Commerce Street; also once known as the Gonzales Road) south and east of the Alamo. The Mexican Permanent Battalion, Jimenez, was also placed east of the fort. Williams (1933: 29) also notes that a skirmish took place between Sesma's cavalry and a detachment of Texans east of the mission on February 26, 1836 but does not give details.

The actual attack on March 6, 1836 included four columns, the third of which was under the command of Col. Jose Maria Romero attacking from the east 


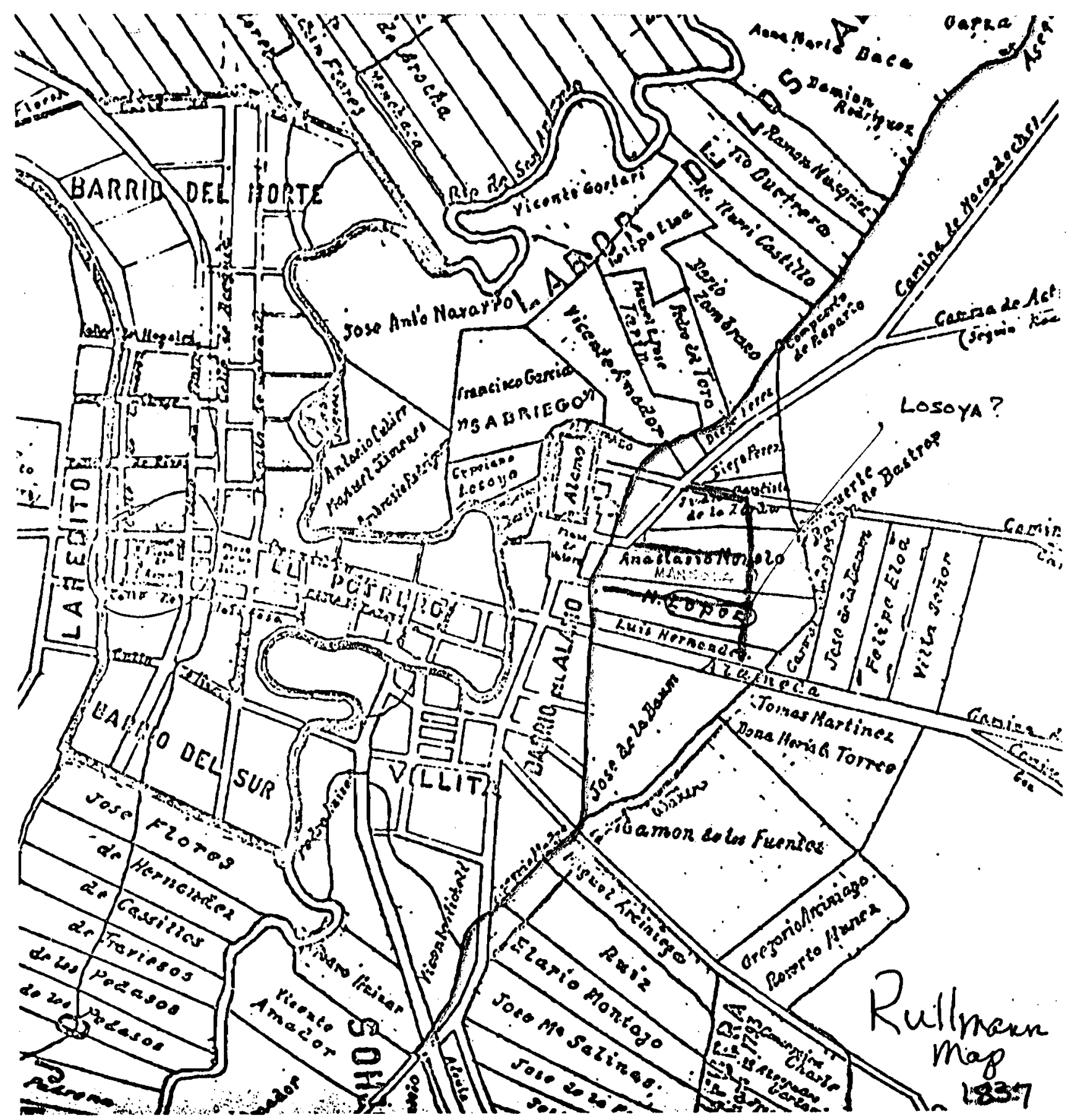

Fig. 6 Rullman's map of San Antonio, 1837. On file at the DRT Library, The Alamo. Approximate areas of modern streets are in yellow. Note inconsistency of "M. Lopez" suerte with other documentary evidence. Note also the possibility of acequia lateral canals along original boundary lines. 
(Figure 7). Consisting of two (rifle) companies of fusiliersfrom the Matamoros and Jimenez battalions, their total strength was ca. 300 men. This force, attacking the strongly defended east wall, was bloodily repulsed by heavy cannonfire that eventually diverted the attack to the northeast wall (de la Pena 1975: 47-48). The cavalry, under Sesma, maneuvered south and east to intercept any escapees.

The eventual funeral pyre(s?) from this battle have been an interesting footnote in the histories that have followed. The actual location of the pyre(s) has been lost in the historical record and the accounts that exist often conflict. Various sources have placed it east of the mission (see Markey 1981) and the CAR-UTSA thought it might be in the 1010 block of the Las Tiendas Project area.

In summary, the period from ca. 1720 to the mid-19th century is poorly documented for the project area. Potential features related to the mission era of San Antonio de Valero, such as a network of acequia lateral canals, early jacal structures outside the compound or battlefield-related materials associated with the storming of the Alamo in 1836, may exist in the general area but are undocumented in the historical record. While the long-term urbanization of San Antonio has no doubt destroyed much of the evidence of early activities around Mission Valero, the cultural resources potential of this area is considered quite high. 


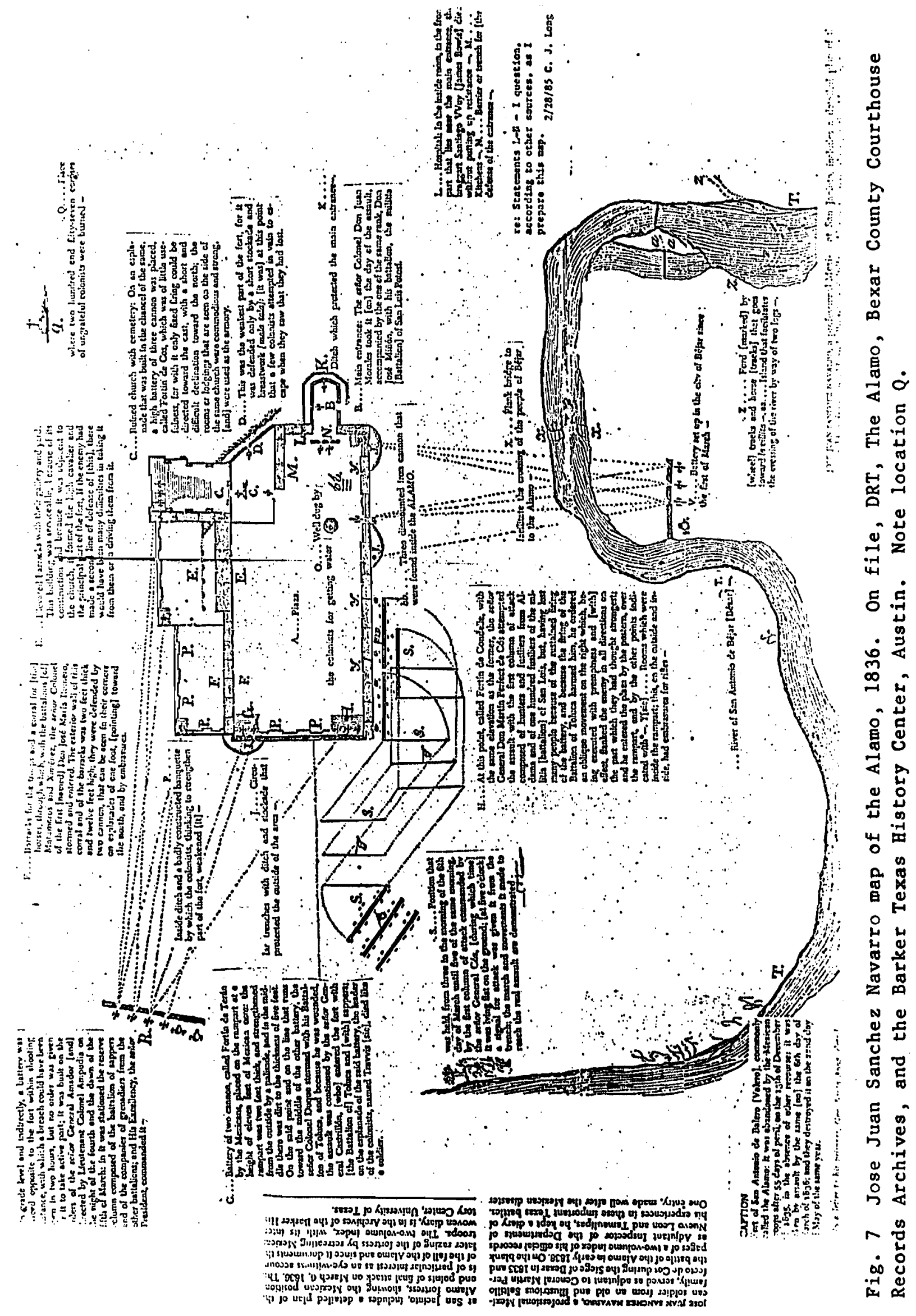


Historical Summary

(CAR-UTSA continuation; extracted from Cox 1987:2)

The area-was a portion of the lands awarded to Mission San Antonio de Valero after its re-location in 1724 (Habig 1977:35). In 1793, the Mission was secularized and the lands were divided among the mission Indians and other citizens. The area in question was awarded to Juan Bautista de la Zerda, a refugee from the Los Adaes settlement abandoned by the Spanish in 1773 (Spanish Archives Vol. III:229, Bexar County Courthouse). In 1839, Asa Mitchell purchased the de la Zerda property from Casanio Zerda, heir to the estate of Antonio de la Zerda and his wife, Josefa Mitchell, for $\$ 200$ (Bexar County Deed Records, BCDR, A2:159). The land'was purchased, in 1849, by John J. Giddings and platted for subdivision. He named the streets for Alamo heroes (Bonham, Bowie, Crockett, and Travis). The names are retained in the area but there has been some shifting of location. Travis Street, ca. 1851, was re-named East Houston, and the upper portion of Bonham Street was originally called Nacogdoches Road. Developments of the area are illustrated in Figures 8, 9, and 10 .

A continuation of the background archival/historical research for the period of ca. 1850 - present was conducted by the CAR-UTSA. This work, block and lot specific, was compiled by W. Cox (1987) (CAR-UTSA). Cox's history of the lots has been extracted and included as "Historical Background" in lot descriptions of Section I I (Limited Testing). His work describes the East Houston Street area between Bonham and Bowie Streets. This work is qualitatively different from the research/interpretive approach used to assess the earlier cultural 


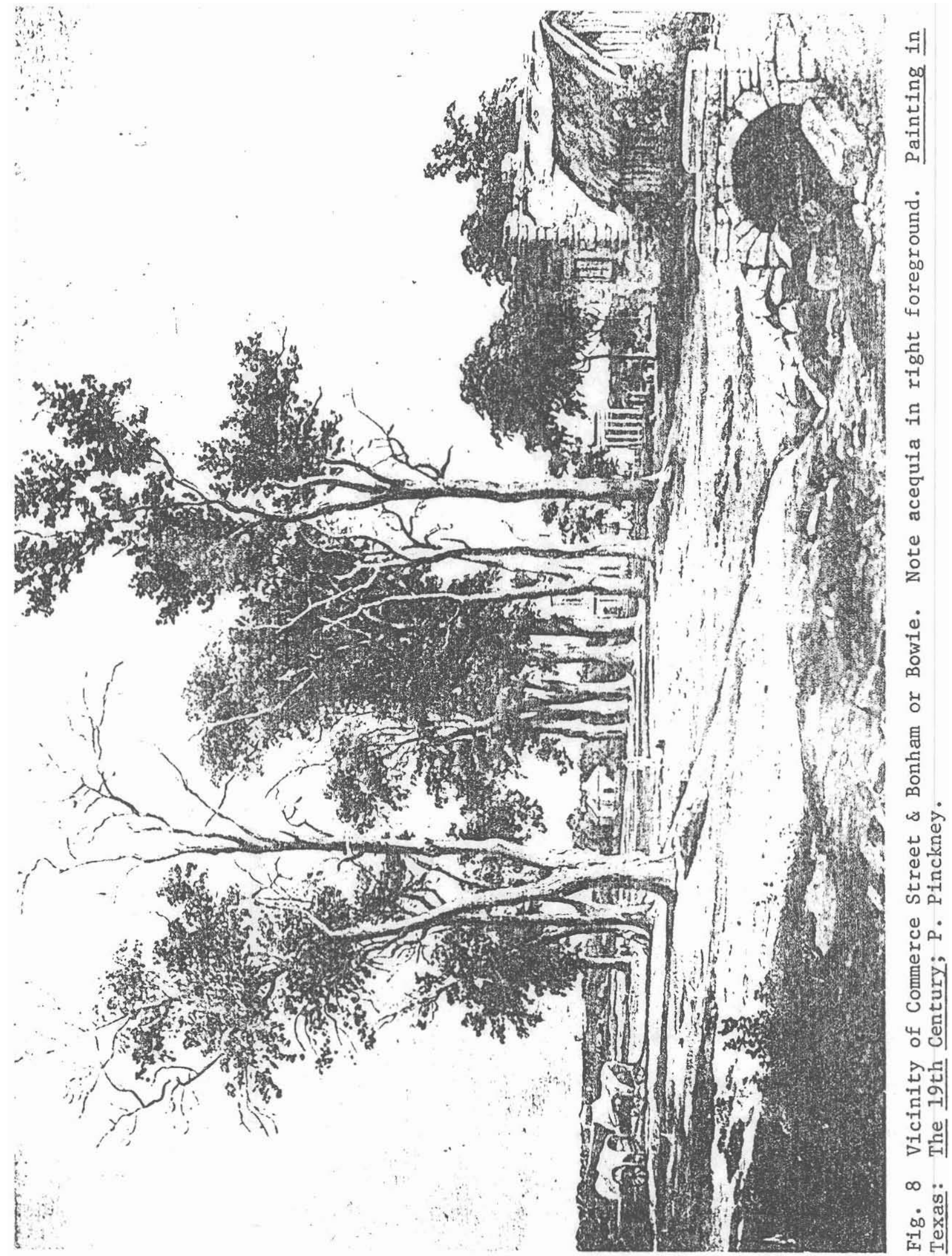



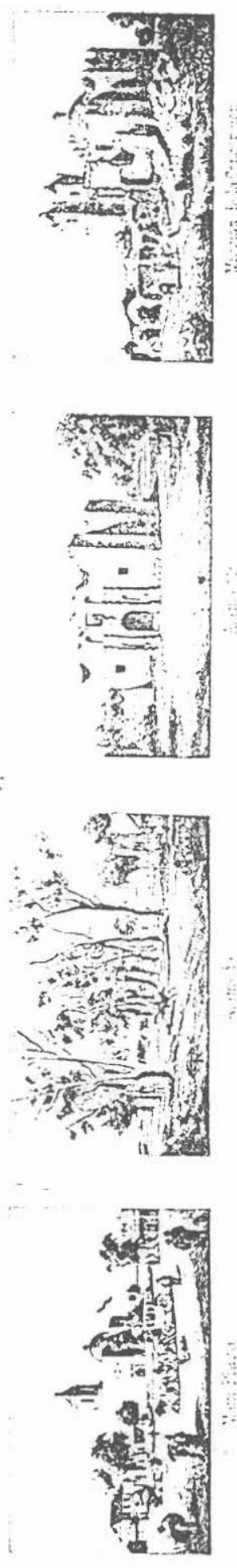

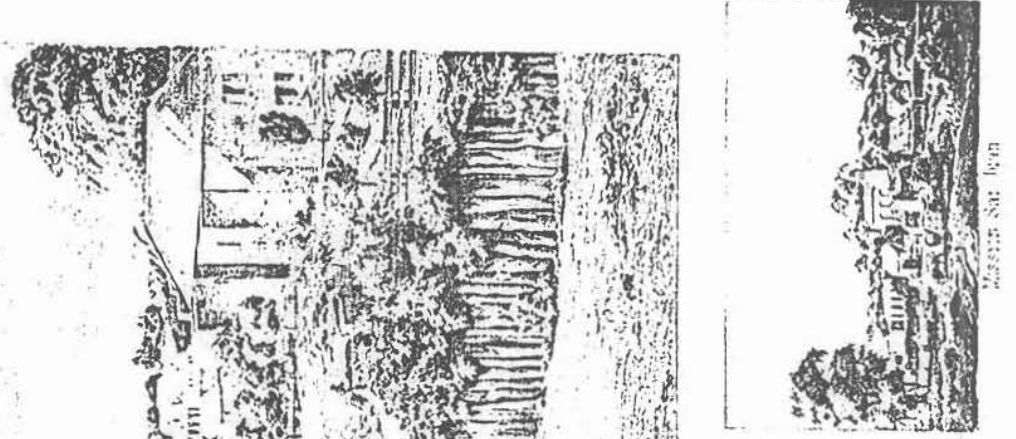

3) Nand
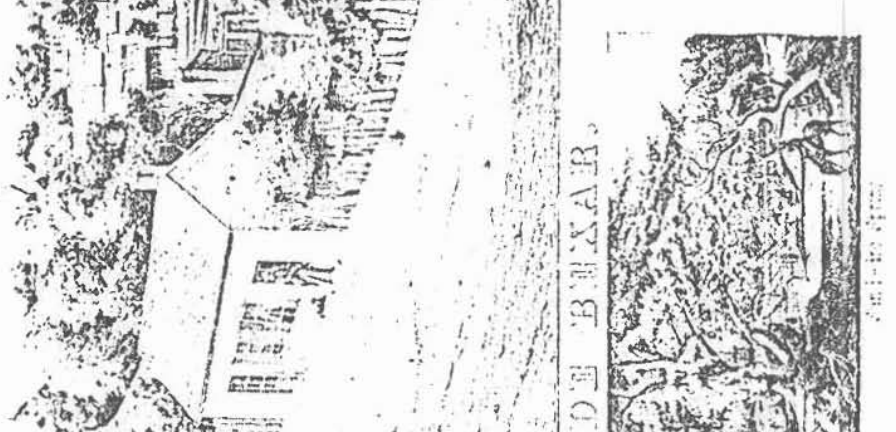

10w
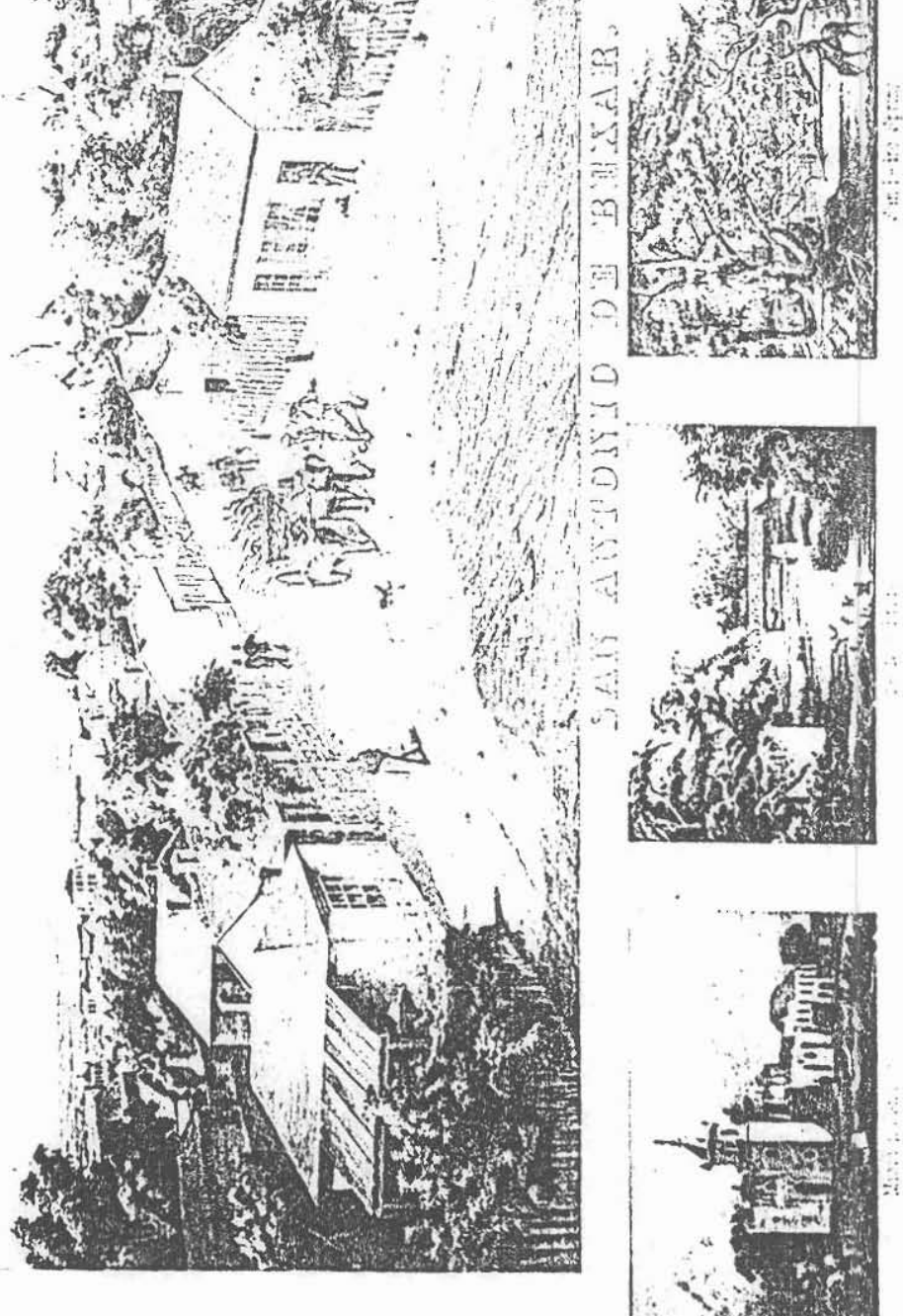

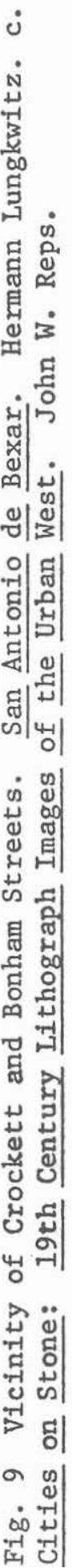




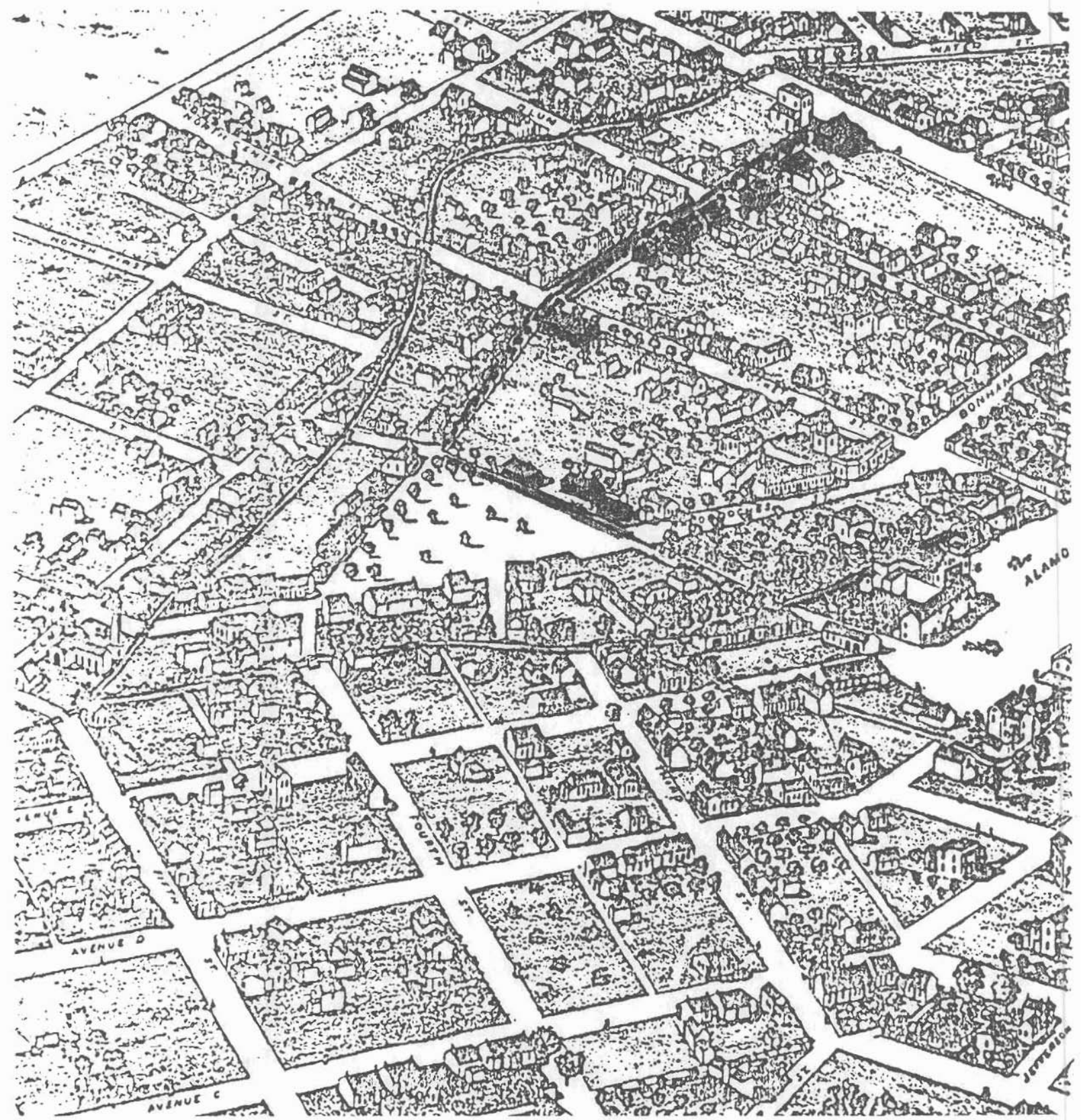

Fig. 10 Koch's Bird's Eye View of San Antonio, 1873. On file, DRT Library, The Alamo. Streets, acequias, and existent structures are noted. 
period developments. In the former, asaessments of potential cultural resources are made in consideration of the lack of supportive documentary evidence; from the period of 1850 - present, recommendations are based on the supportive existence of background information.

Previous Investigations Within the Las Tiendas Mall Area

(CAR-UTSA 1981-1985)

The available CAR-UTSA information is currently unpublished a $\mathrm{n}$ dconsists of four reports:

(1) The Research Design for Las Tiendas Del Rio Project, July 1984, 5 pages.

(2) Preliminary Cultural Resources Assessment for the Las Tiendas Del Rio Shopping Mall Site, San Antonio, Texas, Betty J. Markey, 1981, 40 pages.

(3) Data Recovery Program for Las Tiendas Del Rio Project, April 1985, 25 pages.

This work is supplemented by:

(4) Preliminary Cultural Resources Study of the Houston and Crockett Streets Parking Lots, San Antonio, Texas, I. Waynne Cox, 1982, 15 pages.

Additional work (previously discussed in this report) consists of:

An Archival Analysis of Seven Lots on Houston Street, New City Block 165, San Antonio, Texas, Waynne Cox, 1987, 8 pages.

No final or draft reports are available for the overall archaeological studies of the Las Tiendas Project at this date.

All of the listed works available are preliminary in nature. Item 82 above presents a general overview of the Las Tiendas Project area as of 1981 . The reader is referred to pp 25-32 of this 1981 study, especially section numbers $1,3,5,6,7$, and 11 and pp 33-34, Recommendations. 
Item \#3 above, the data recovery program report, summaries block/lot specific investigations including several features/structures that once fronted along Bowie Street. The 25-page report summarizes both field and archival descriptions of individual property ownerships and structural/feature remains. The report appears to be an interim work and background archival information is more detailed than field data. No quantifiable descriptions of the collected artifacts are presented and no comparisons or interpretations relating to patterns of urban change or inter-block developments are drawn. The report does identify the chronological sequence of activities and, of the 17 lots described, several reflect the remains of structures constructed circa 1850 . The majority represent residences and commercial activities during the turn of the century. Only one lot was identified as containing artifacts earlier than 1861 (Block 1010, Lot 2). No interpretations of these deposits are presented. A city block/Lot map on the following page (Figure 11) is annotated to identify past UTSA work addressed in the 1985 report.

The 1982 I.W. Cox study (listed item \#4) produced an archival review of portions of Houston and Crockett Streets. Applicable to the current work on Houston-Bowie Streets are four lots along E. Houston and two lots that fronted along the corner of Bowie and Crockett Streets. It should be noted that these last two lots once included a late 19th century residence (destroyed in 1913). Cox (personal communication, 2/11/87) indicates the structure may have had a basement. The reader is referred to page 12 of Cox's work for an over-all summary of identified resources in this area.

The CAR-UTSA work is supplemented by the SDHPT collection of lithographs, illustrations, maps, and photographs of Houston-Bowie Streets from mid-19th to 


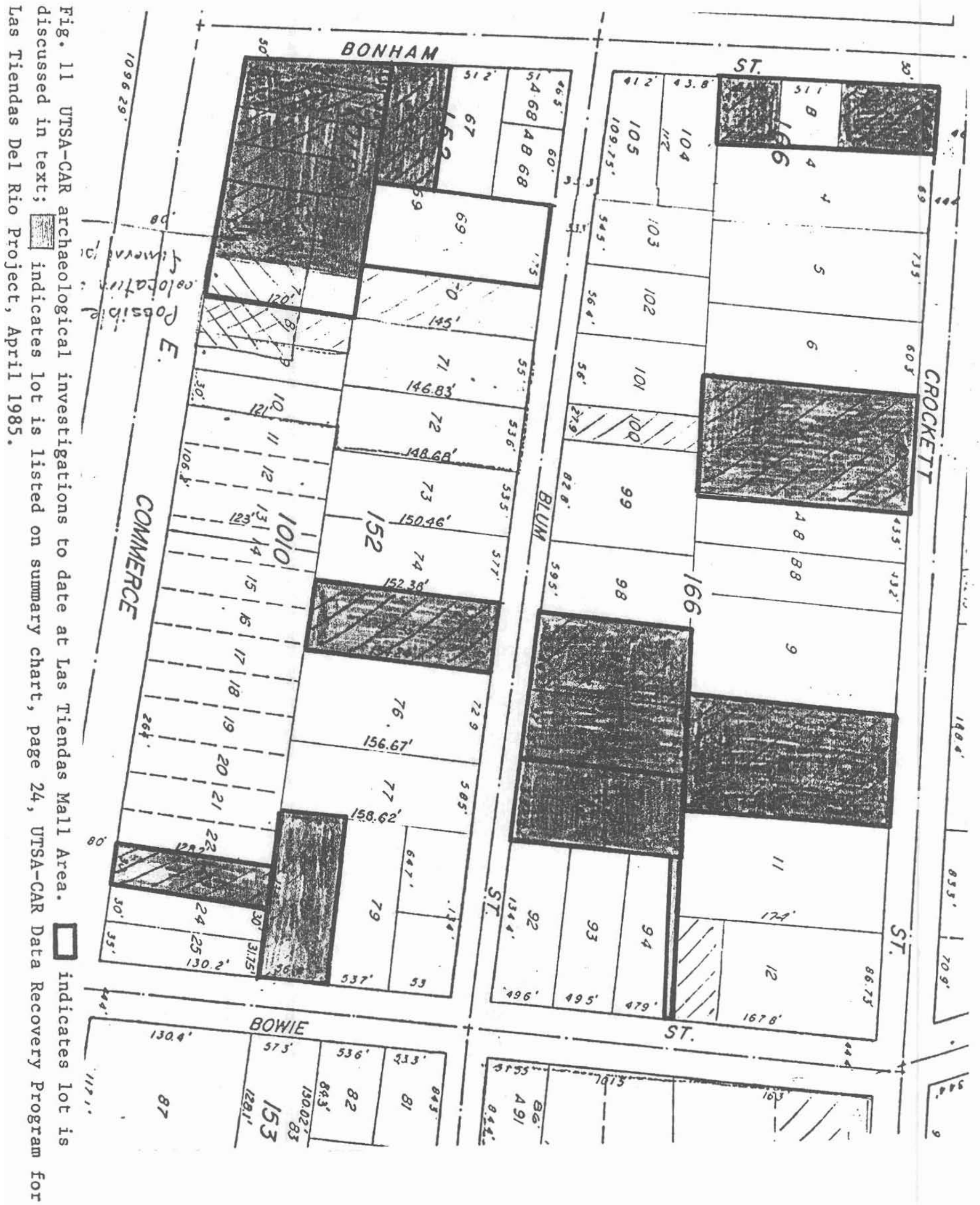


early 20 th century. Of special interest are the photocopies of the 1885-1912

Sanborn insurance maps that detail structures. These may be compared to extracts of Cox's 1987 work in the following section (under "Historical Background" of individual lot descriptions). 


\section{LIMITED TESTING OPERATIONS}

\section{Testing Strategy}

In consultation with the State Historic Preservation Office, Texas Historical Commission, a three-segmented plan of fieldwork was initiated during limited testing. From the perspective of a cultural resources evaluation, the HoustonBowie Streets project was segmented into three divisions (see Figure 12).

These segments were based upon the (1) amount of previous archaeological and historical investigations, (2) the extent of modern alterations and comparable destructive impacts to earlier deposits and, (3) the relative proximity of impacted segments to the Alamo Plaza Historic District.

Individual considerations were thus described as:

1 Bowie Street between Commerce and Crockett Streets

Given the past extent of investigations and destruction of previous structures/deposits during the Las Tiendas Mall construction, the SDHPT recommended on-call monitoring as suggested by the UTSA (Cox 1987) report. Such a monitoring process could easily be handled by the SDHPT and CAR-UTSA in conjuction with the Las Tiendas development.

2 Bowie Street between Crockett and Houston Streets

(New City Block 165; Lots 12, 13, 14, and 29)

Based on the less intensive background studies and the lack of previous field work, a more systematic approach to the monitoring process was initiated. This would encompass on-site inspection of deposits during 


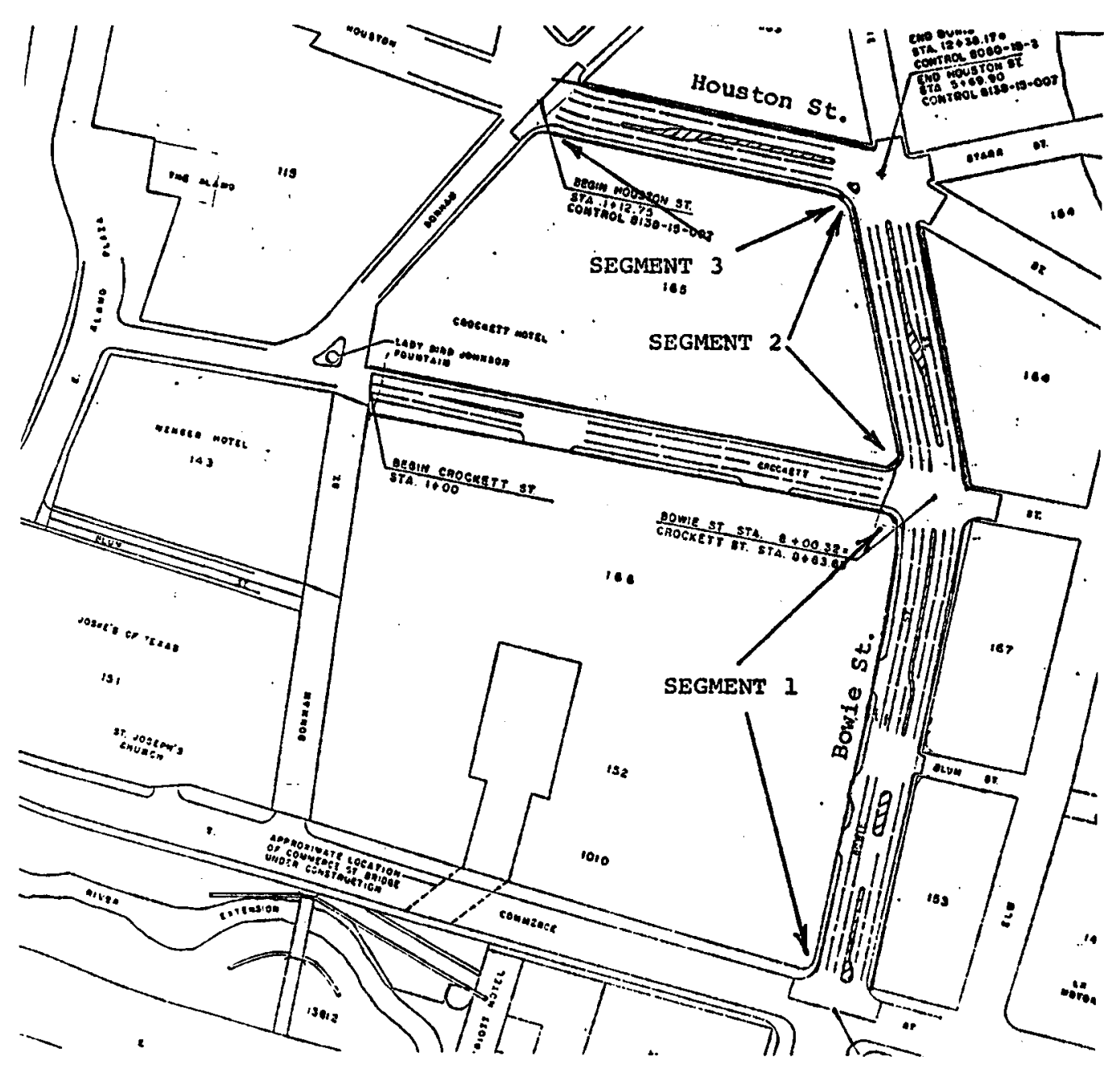

Fig. 12. Project divisions for cultural resources evaluation. 
construction activities that impact new right-of-way sections and the photographic and record documentation of features and structural remains. Additionally, it was possible that a lateral segment of the Acequia Madre might be found in this area beneath present-day Bowie Street, perhaps along the 300 block (see Rullmann's 1837 map of San Antonio; Figure 6). It was anticipated that such monitoring as well as further archival research would be concurrent with all construction work and would not delay the latter. Additionally, such monitoring, although periodic and systematic, would take place only during the uncovering of new right-ofway. Such work would be conducted by SDHPT archaeologists.

3 Houston Street between Bowie and Bonham streets (Lots 23, 24, A25, 25, 26, A27, B27, 28, portions of Lot 29) It is reasonable to assume that as subsurface disturbances approach the Alamo Plaza Historic District, the more likely the possibility of uncovering previously unidentified cultural materials associated with the complex. Given this potential for unrecorded subsurface deposits and in light of the paucity of background information for the early historical period, a program of monitoring was considered inadequate. Limited testing was deemed more appropriate in order to (1) determine the actual existence of potentially early deposits that are not documented historically, (2) identify the extent of past disturbances in the area and, (3) determine the presence of anticipated deposits and their cultural integrity. Additionally, such features as late 19 th century wood street paving blocks, when uncovered, should be treated as archaeological artifacts/features. Before their removal to a city museum (Pat Osborne, City Historic Preservation Officer, Personal communication 2/11/87) these 
materials should be uncovered, documented, and removed by current archaeological standards. Additionally, photographic and record documentation of work as well as a continuation of general and specific archival research was recommended.

The testing, as deemed appropriate, was limited in scope and scheduling. It was anticipated that such testing would be ca. three weeks in duration and be dependent upon construction concerns. Conducted concurrently with street modifications, no loss of construction scheduling was anticipated. Prior to testing, coordination was established with the City's managing consultants, construction crews, and other affected parties. Such work, consisting of machine trenching and hand-excavated 2-meter.square units utilizing standard recovery techniques, as appropriate, was conducted by SDHPT archaeologists and personnel. A detailed description of field work is presented below.

\section{Summary of Archaeological Testing}

\section{$\underline{\text { Introduction }}$}

During March and April 1987, the SDHPT initiated a program of archaeological investigations along portions of Houston and Bowie Streets, in downtown San Antonio. Hand and mechanical testing was conducted by A. McGraw of the SDHPT Cultural Resources staff, who supervised from seven to nine support personnel from the San Antonio SDHPT residency. A total of 17 working days were expended during field operations that investigated new right-of-way locations within 12 separate lots in New City Block (NC131) 65 along Houston and Bowie Streets (see Figure 13).

The field work, preceded by a preliminary historical/archival review of the project area, was accomplished in accordance with the Memorandum of Agreement (MOA) for the Las Tiendas Mall Project under the auspices of 36 CFR 800 . 


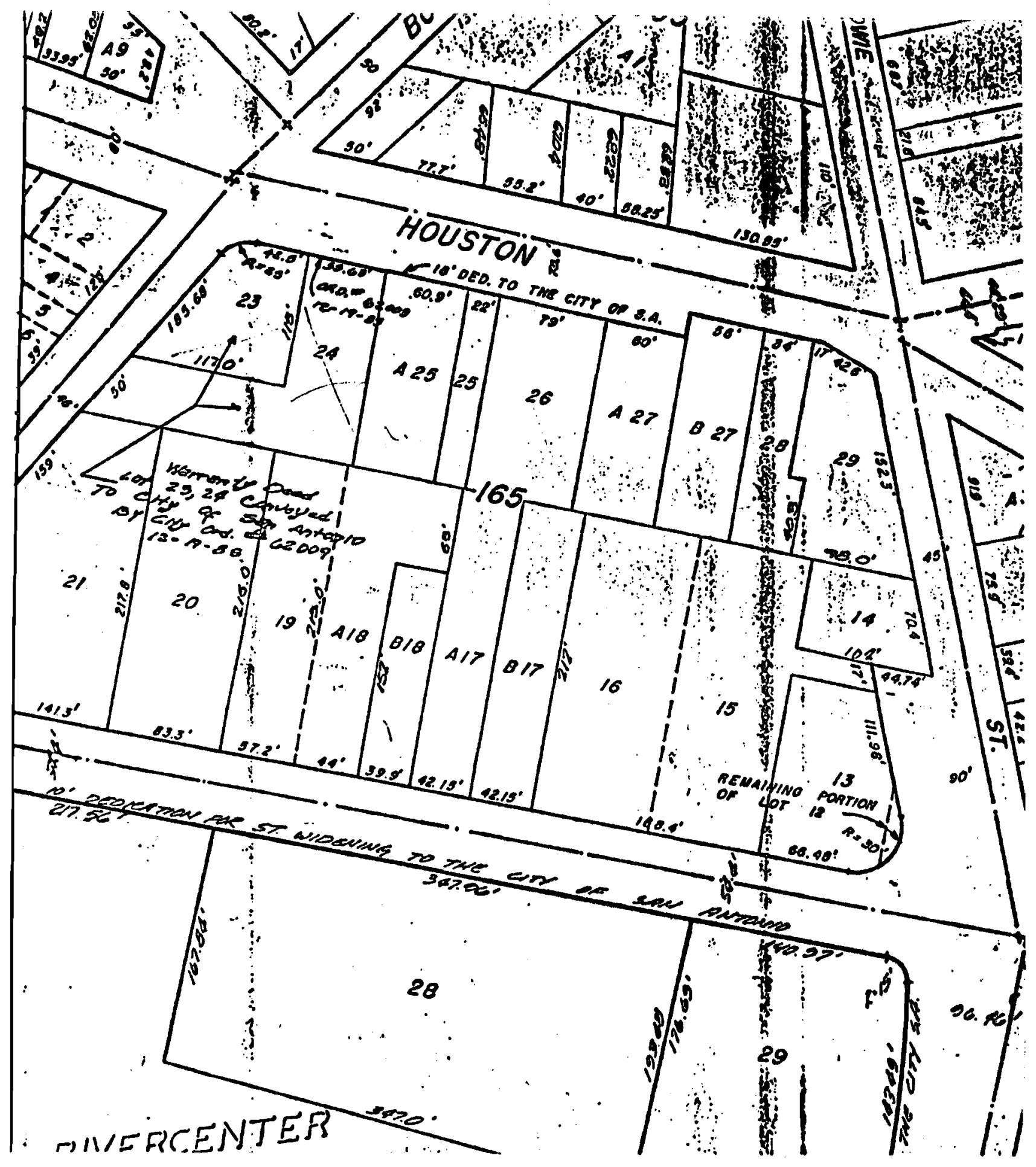

Fig. 13 New City Block 165 along Houston-Bowie Streets. 
Archaeological testing recovered materials and identified structure features dating from the late Texas Republic Period through recent times, of the 12 investigated lots, three are recommended for further work based on criteria D for listing on the National Register of Historic Places: "have yielded, or may be likely to yield, archaeological information important in ....history." A description of testing objectives, summary of work by individual lot, and recommendations for further work are presented below. Impacts to the project not related to the SDHPT operation but which will affect the local cultural resources are also addressed.

Field Methodology

A permanent bench mark near the corner of Houston and Bonham street was utilized for vertical control and mapping of tested areas. Although having a mean sea level (msl) elevation point of $660.30 \mathrm{ft}$. (above msl), this was converted to an arbitrary 100.00 for compatibility during metric instrument use. This datum point was used for transit and plane table/alidade mapping operations in all areas of the project. Such a consistency of elevation data was thought to be useful for comparisons and correlations of natural stratigraphy and cultural deposits across the 12-lot area.

Mechanical testing was utilized whenever possible to quickly identify areas of cultural deposits as well as to break surface asphalt and remove disturbed base materials. All mechanically-excavated materials were inspected for artifacts and changes in natural soil deposits. When artifacts were recovered by trenching, the excavated dirt was set aside for screening through 1/4" wire mesh.

Hand excavation utilized standard archaeological recovery techniques. 
Lots 23 and 24 Historical Background

NCB 165, Lot 23

On March 3, 1849, Giddings sold this corner lot to Charles Morris for $\$ 100$, which at that time had a frontage of $213 / 4$ varas (65.95 feet) on Nacogdoches Street, the present Bonham Street (BCDR H1:105). In 1852, Morris engaged an attorney, Peter Pauly, to recover unpaid rents from Charles Kahn, indicating that a rental structure had been erected at least by that time (BCDRK2:281). In July of 1854, Charles Morris entered into an agreement with Edward Elmendorf to allow Elmendorf to "build and erect" an addition to the premises. Elmendorf was apparently the renter at that time (BCDR M1:182). In 1859, Elmendorf purchased the property from Morris fdr \$1600 (BCDRR1:571). In December of 1861, Elmendorf transferred the property to his wife, Emilie (BCDR S2:189). Elmendorf died in 1865 (Chabot 1937:404). Emilie, now re-married to Herman Kramer of Dusseldorf, Prussia, sold the property, with "all buildings and improvements", to Honore Grenet in 1871 (BCDR W1:2930). In 1872, Grenet purchased the adjoinging lot and re-located the property lines, and constructed a warehouse on the southern portion of thelot, now part of Lot 24. In 1877, Grenet had a store and residence located to the south on what is now the site of the Crockett Hotel, and in 1879, he moved his store to the Alarno grounds but maintained his residence on Crockett Street (City Directories 1877, 1879, 1881). Grenet was found dead in his bath tub, February of 1882 (Chabot 1937:263). In 1884, his estate sold the property, with Lot 24, to Sam Maverick. Lot 23 sold for \$4275 and Lot 24 for \$2225. (BCDR $40: 46$ ). The insurance maps, for 1885 and 1888, show the warehouse and a small stone or caliche block structure facing on Houston Street, but by 1892 the warehouse is no longer shown (Sanborn 1885, 1888, 1892). In 1903 the 
house was rented to L. Oroposa and in 1905 to R. Becker (City Directories 1903-4, 1905-6). In November of 1906, the Maverick estate sold both lots to V. A. Petty, and three months later, V. A. and Cerdilia Petty sold them to James Byrne for \$10,000 (BCDR $255: 560$, 266:71). In 1908 Thomas L. Conroy and Hugh B. Rice purchased a half interest in both lots from Byrne, probably indicating that the original structure had been replaced by a commercial venture (BCDR 281:365). They still owned the property in 1914 when Houston Street was widened and the deed required the city to "re-model the building now on the premises' (BCDR 778:386). In 1986, the city purchased the property from Marguerite Wurzbach (BCDR 1411:604).

NCB 165, Lot 24

In 1849, Giddings sold this lot to Louis and Theresa Horning, and they sold the lot to Grenet in 1872. In 1884, the Bonnets sold the western half (Lot A25) to Adolph Scholz, who owned the lot to the south on Crockett Street (BCDR 33:65). However, there is no indication that Scholz ever resided at either address. The structure was still standing until at least 1905 (Sanborn 1885-1904). In 1903, it was rented to A. T. Hughes, and in 1905 to Mrs. R. M. Reynolds (City Directories 1903, 1905). In 1906, the property was purchased by Mrs. Edward Thompson, Jr., who sold it to Martha M. Tong, whose home was on the adjoining lot (BCDR 345:431). She, in turn, sold the property to A. B. Weakley in 1910 (BCDR 345:431). In 1915, the property was owned by Adolph and Amanda Wagner (BCDR 778:392). In 1985, the city purchased this lot, along with Lots 26 and 27, from the Quanta Corporation (BCDR $3557: 676$ ). 
Field Investigation

Modern land usage has combined Lots 23 and 24 into an asphalt-paved, commercial parking lot. Little remains of the earlier lot boundary line except a service entrance to the parking lot that is along lot line 23 and 24 .

The lots were investigated using both mechanical and hand testing. Mechanical trenching consisted of a backhoe with a narrow-width toothed bucket to break through asphalt and compacted, disturbed base materials (see Figure 14).

Tables 1 and 2 summarize the types and depths, as well as materials recovered or features identified during Testing in Lots 23 and 24. The description of test units is separated by individual lots but'the numbering is consecutive as the area has been combined into one parking lot.

Table 1. Summary of Excavation Data, Lot 23 Maximum Depth Recovered M aterials/ $\underline{\text { Test Unit }}$ Type of Unit Dimensions Below Surface Features Noted

Lot 23

\begin{tabular}{|c|c|c|c|c|}
\hline \multicolumn{5}{|c|}{$\overline{\text { Mechanical Testing }}$} \\
\hline 1 & Trench 1 & $\begin{array}{ll}\text { ca. } & 2 \times 5 \\
\text { meters }\end{array}$ & $99.97-98.86$ & $\begin{array}{l}\text { modern disturbance, to } \\
\text { floor of trench; small cut } \\
\text { bone deposit exposed at } \\
98.86 ; \text { see Test Unit } 4\end{array}$ \\
\hline 2 & Trench 2A & $\begin{array}{l}\text { ca. } 5.3 x \\
1.32 \text { meters }\end{array}$ & $99.97-98.37$ & $\begin{array}{l}\text { limestone rock rubble wall } \\
\text { foundations c/ small } \\
\text { residence exposed } \\
70-110 \text { om below surface; } \\
\text { see Test Unit } 5 \\
\text { (Figures } 15,16)\end{array}$ \\
\hline 3 & Trench 2B & ca. $1 \times 4$ & $99.97-99.01$ & $\begin{array}{l}\text { extensive disturbances to } \\
99.27 ; \text { no features noted }\end{array}$ \\
\hline \multicolumn{5}{|c|}{ Hand-Excavated } \\
\hline 4 & 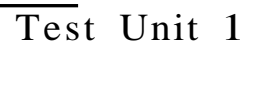 & $1 \times 2$ meter & $98.86-97.56$ & $\begin{array}{l}\text { Cut bone, ceramics in } \\
\text { small trash pit; see text }\end{array}$ \\
\hline 5 & Test Unit 2 & $1 \times 2$ meter & $99.37-97.92$ & $\begin{array}{l}\text { Exposure of rubble foun- } \\
\text { dation; see text }\end{array}$ \\
\hline 6 & Test Unit 3 & $1 m^{2}$ & $99.40-97.90$ & sterile \\
\hline
\end{tabular}




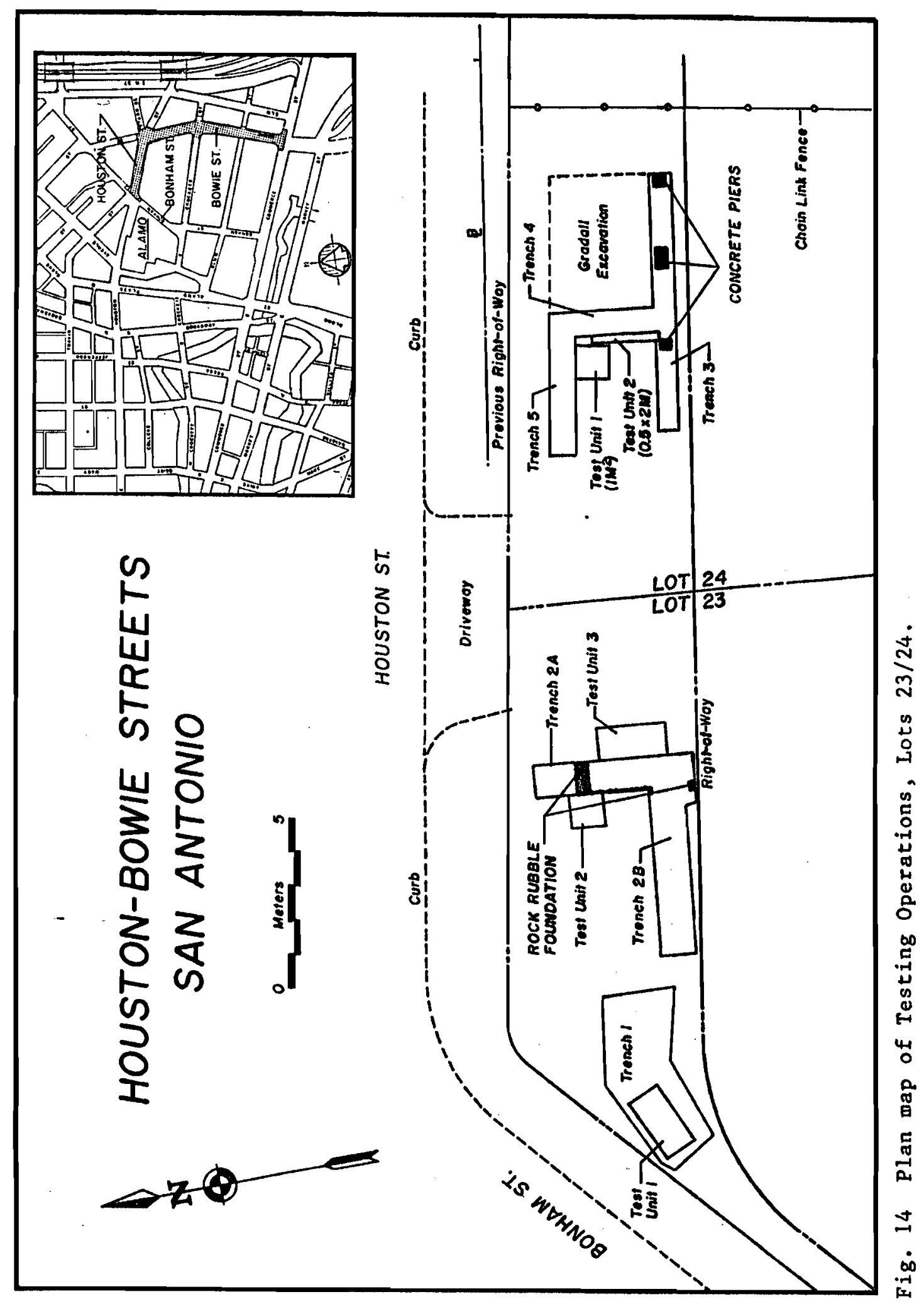




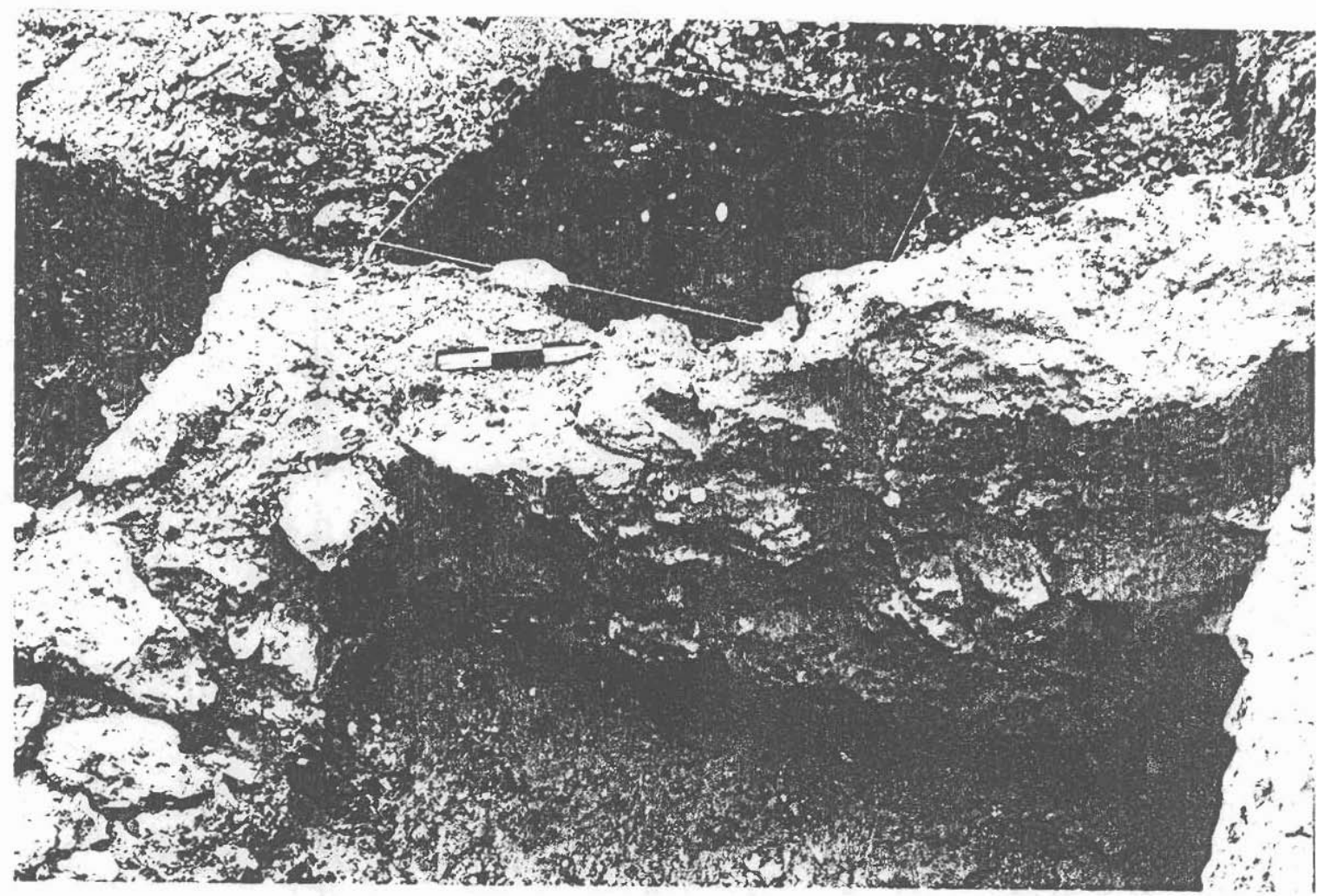

Fig. 15 Close-up of rock-rubble foundation circa 1840-1850 exposed in Lot 23.

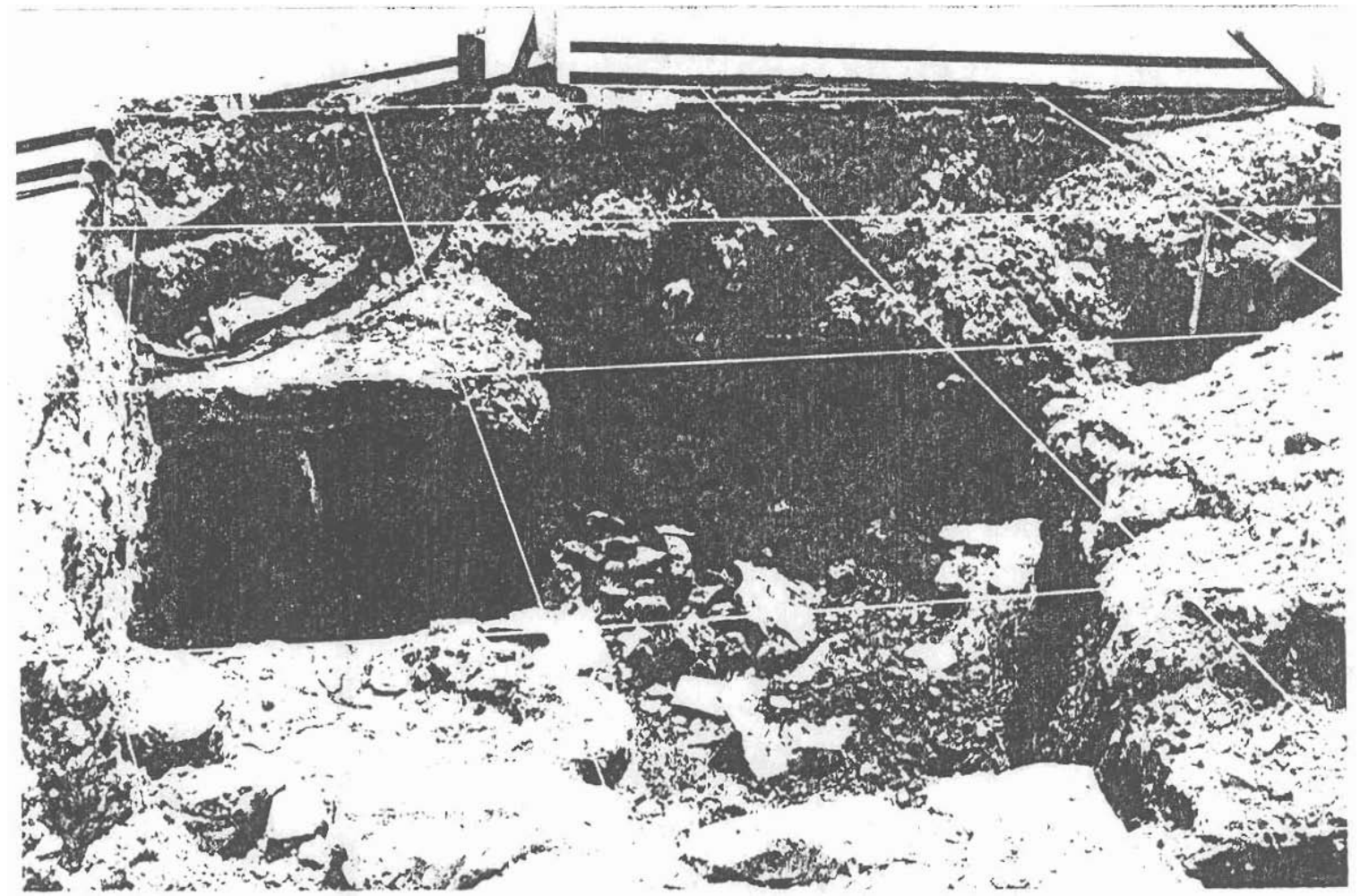

Fig. 16 Overview of wall/foundations in Lot 23 
Table 2. Summary of Excavation Data. Lot 24. NCB 165

\section{Test Unit Maximum Depth Recovered Materials/ \\ Test Unit Type of Unit Dimensions Below Surface Features Noted}

Mechanical Testing

\begin{tabular}{|c|c|c|c|c|}
\hline 1 & Trench 3 & $\begin{array}{l}0.5 \times 7 \\
\text { meters }\end{array}$ & $100.02-98.56$ & $\begin{array}{l}\text { concrete piers (see text) } \\
\text { (see Figures } 17,18 \text { ) }\end{array}$ \\
\hline 2 & Trench 4 & $\begin{array}{l}0.5 \times 3 \\
\text { meters }\end{array}$ & $100.02-98.56$ & concrete piers (see text) \\
\hline 3 & Trench 5 & $\begin{array}{l}0.5 \times 4 \\
\text { meters }\end{array}$ & $100.02-98.56$ & $\begin{array}{l}\text { disturbed cut, burned } \\
\text { bone/trash deposit at ca. } \\
98.95-98.70 \text { (see Test } \\
\text { Unit 1) }\end{array}$ \\
\hline 4 & $\begin{array}{l}\text { Gradall } \\
\text { Excavation }\end{array}$ & $4 \times 4$ meters & $100.02-98.56$ & $\begin{array}{l}\text { extensively disturbed } \\
\text { deposits }\end{array}$ \\
\hline \multicolumn{5}{|c|}{ nd-Excavations } \\
\hline 5 & Test Unit 1 & $1 \mathrm{~m}^{2}$ & $98.95-98.70$ & see text \\
\hline 6 & Test Unit 2 & $\begin{array}{l}0.5 \times 2 \\
\text { meters }\end{array}$ & $98.86-98.56$ & $\begin{array}{l}\text { disturbed deposits, see } \\
\text { text }\end{array}$ \\
\hline
\end{tabular}

A Gradall, using a wider, smooth bucket and capable of excavating to within a few centimeters vertically was also employed for excavations in less disturbed lower soil deposits. All removed materials were inspected and/or screened through 1/4" wire mesh prior to final removal. Due to the high vehicle and pedestrian traffic in the immediate area, trenches, after recording and documentation, were not ordinarily left open unless absolutely necessary. Three mechanically excavated trenches were placed in Lot $23(1,2 \mathrm{~A}, 2 \mathrm{~B}$, see Figure 14). Trench 1 measured $2 \times 5$ meters and was located near the corner of Houston and Bonham streets. Trenches $2 \mathrm{~A}$ and $2 \mathrm{~B}$, an L-shaped excavation, were undertaken just to the east of Trench 1 and ca. 4.5 meters west of the original property boundary of Lots 23 and 24 . 


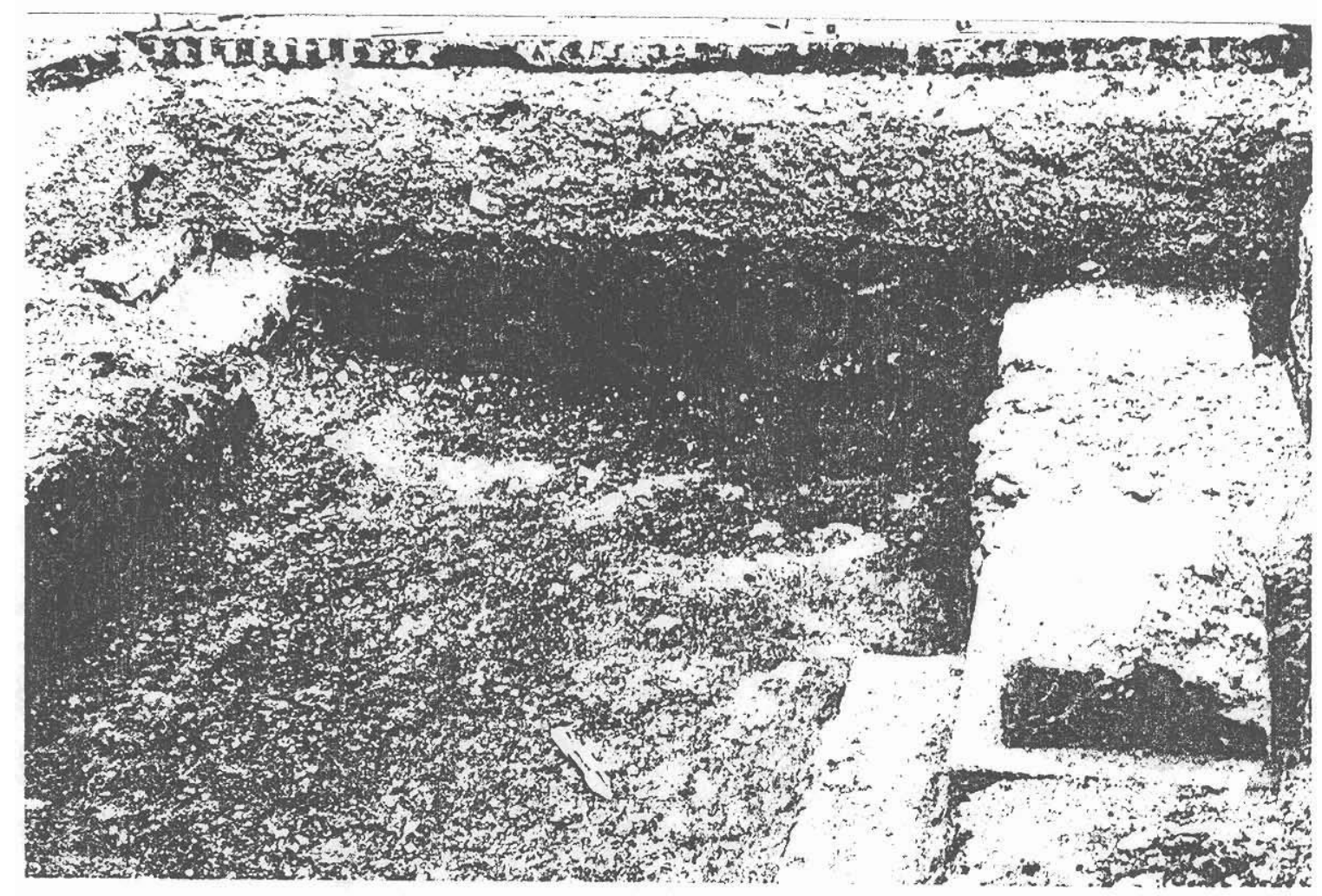

Fig. 17 Close up of concrete pier excavated in Lot 24.

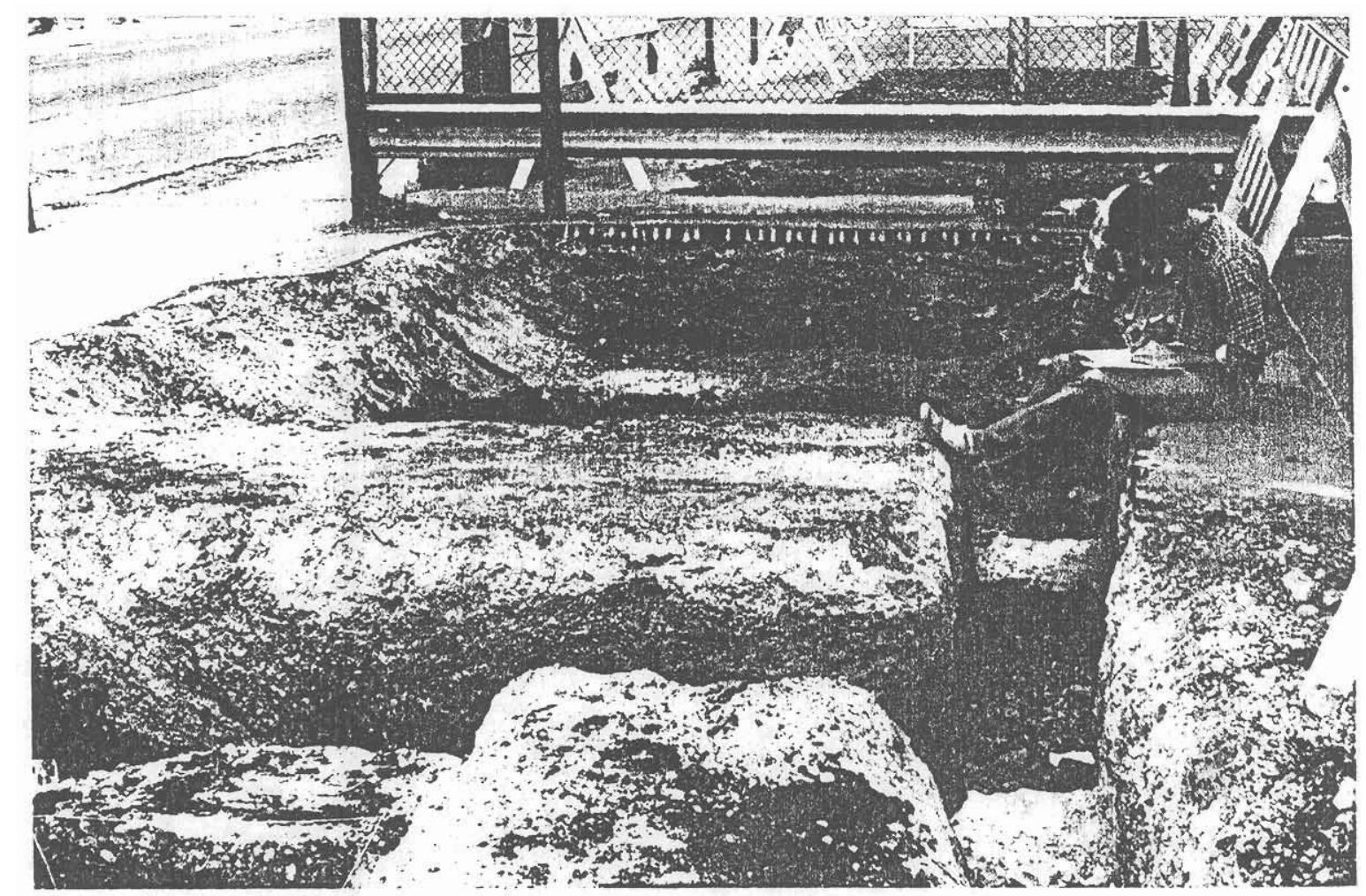

Fig. 18 Mapping of early 20th century concrete foundation piers from commercial structure in Lot 24. 
A total of four hand excavated units (see Tables 1 and 2) were excavated in Lots 23 and 24.

Test Unit 1, 1 x 2 meter, in Lot 23, uncovered a small burned and cut bone deposit that included a light scatter of ceramic fragments and household materials at a depth of 98.86-98.43. This cultural deposit, given the chronological range of ceramic wares recovered, is estimated to be ca. 1840-1850 and similar to less well defined (and more disturbed) deposits in Lot 24 at approximately the same elevation; for example Test Unit 1 in Lot 24, or the lower cultural deposits at Test Unit 2, Lot 23.

A preliminary comparison of archaeological testing data and historical research indicates: (1) that intact cultural deposits exist along portions of the new right-of-way; (2) these deposits consist of cultural materials dating to the Texas Republic/Early Statehood historical periods as well as more modern early 20th century commercial refuse. Structural features in Lots 23 and 24 include a rubble-stone foundation with an estimated construction date circa 1840's as well as turn-of-the-century concrete pier foundations (Lot 24) of a two-story brick garage/business complex. The rubble-stone foundation is thought to be the remains of a small residence which dates to at least 1849 and was in existance until 1905, as identified on Sanborn Insurance maps of San Antonio for that period (see Figures 19, 20, 21). Note also the commercial developments by 1912. The commercial structures on Lots 23 and 24 are shown on the 1912 Sanborn map.

In the opinion of the SDHPT and with the concurrence of the State Historic preservation Officer, Texas Historical Commission, further work is necessary to more accurately describe the background and historical context of the 


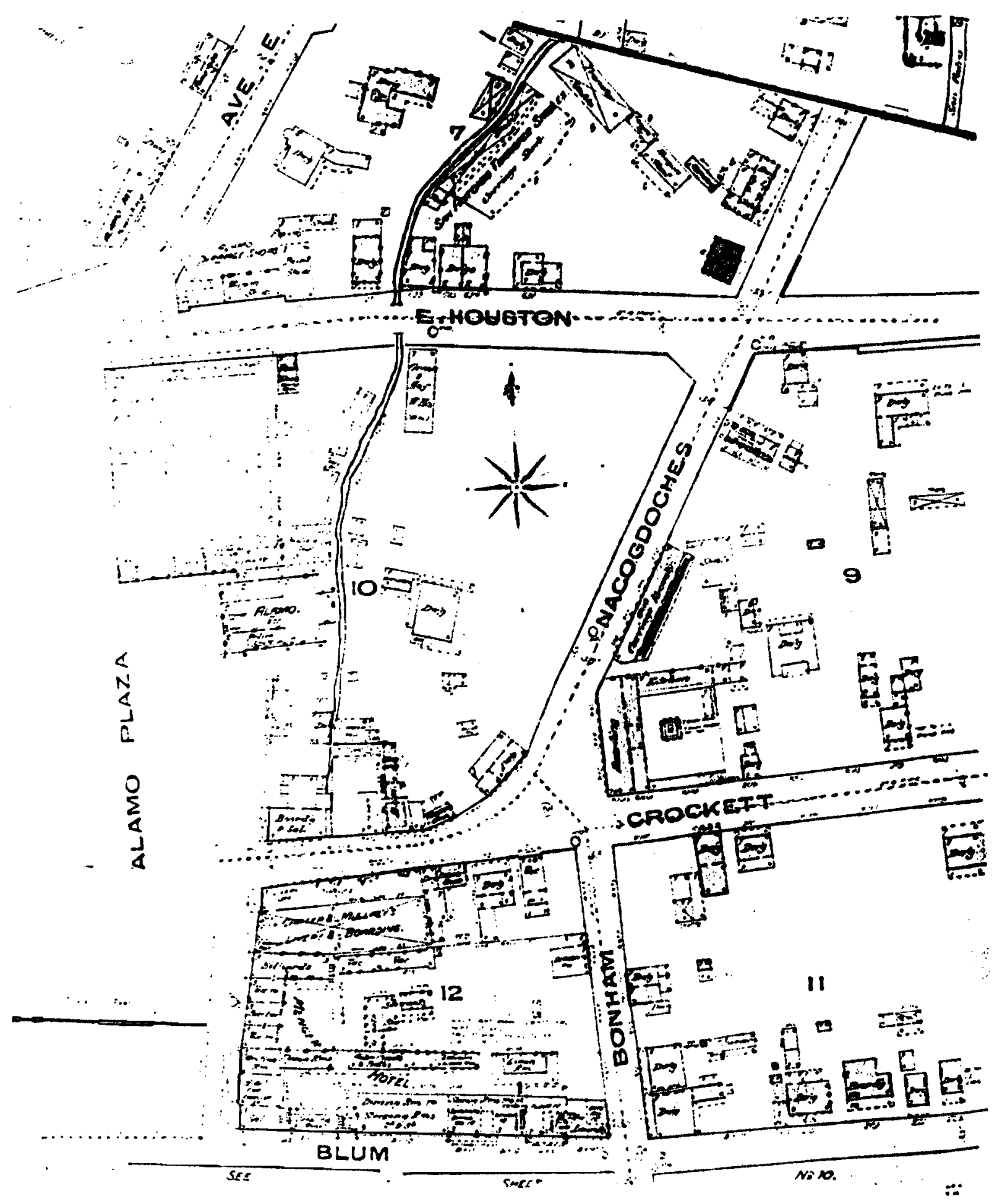

Fig. 19 Sanborn Map, 1885. Barker Texas History Center. Structures located near Houston and Nacogdoches (Bonham) Streets. 


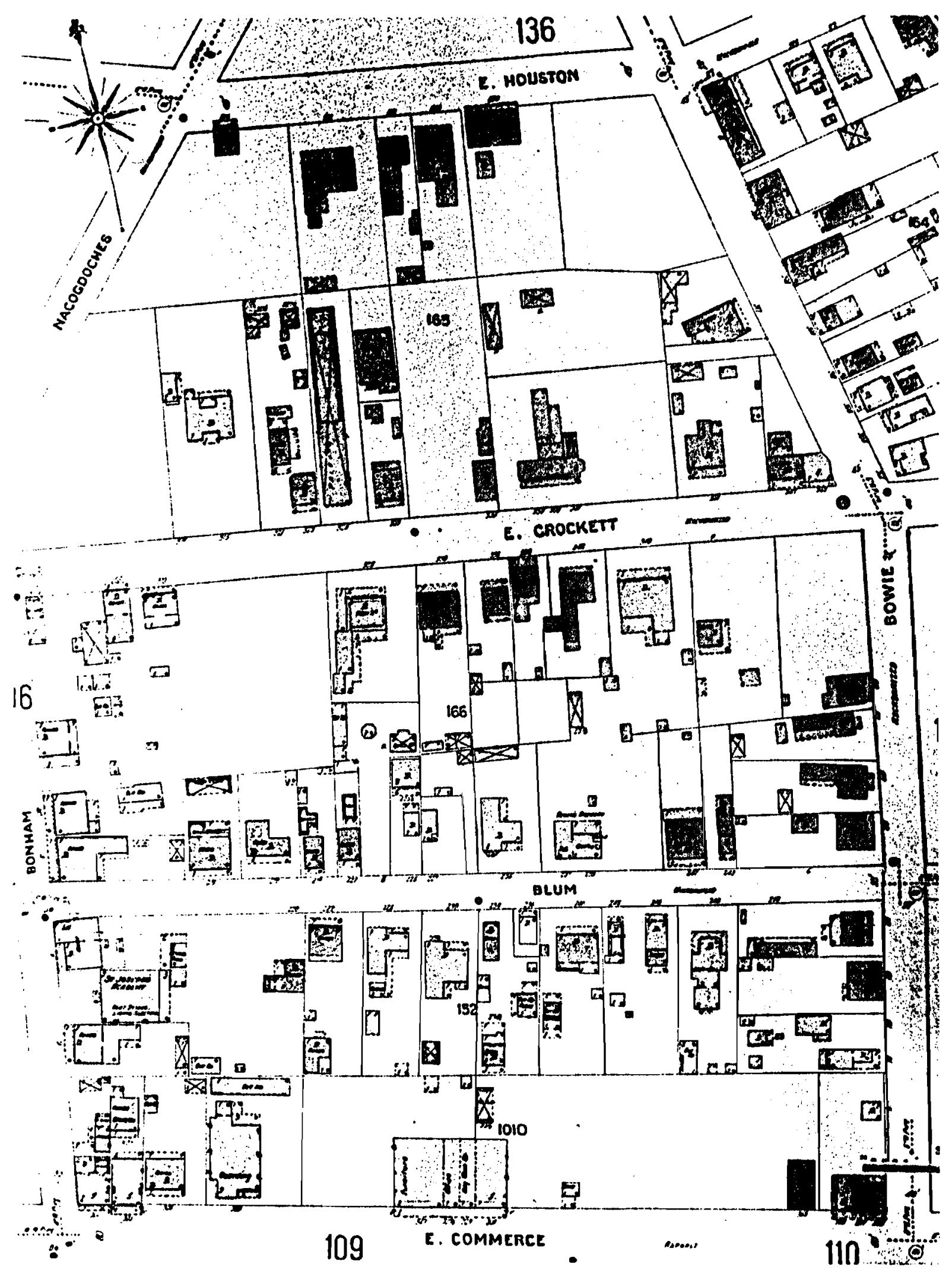

Fig, 20 Sanborn Map, San Antonio, 1904. On file, Barker Texas History Center, Austin. 


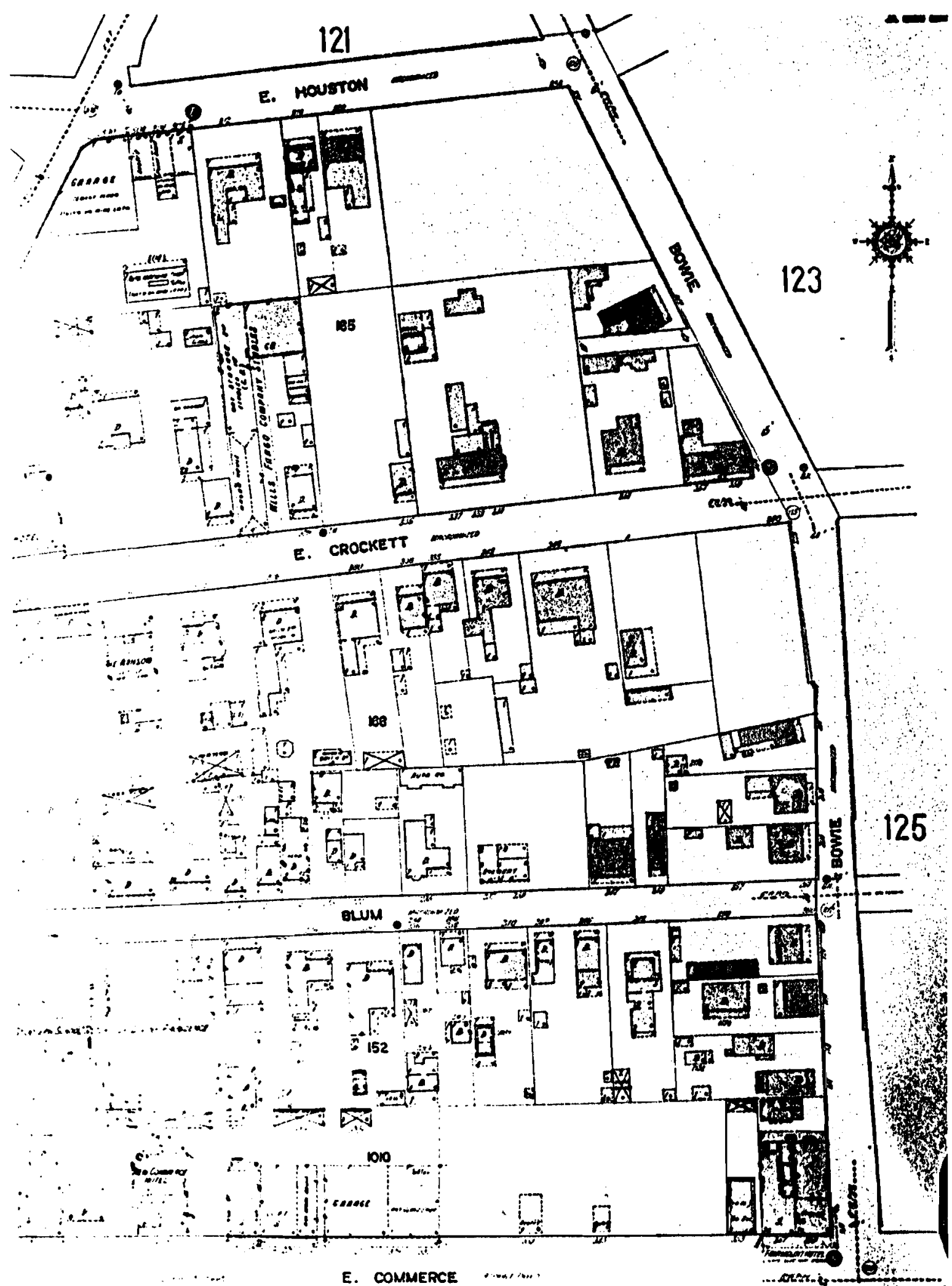

Fig. 21 Sanborn Map, San Antonio, 1912. On file, Barker Texas History Center, Austin. 
features and materials under direct impact in Lots 23 and 24. See

Recommendations For Further Work section for specific proposals for such work.

Lot A25, 25 Historical Background

(extracted from Cox 1982:9)

In 1849 Giddings sold this lot to Joseph Humbrach, who in turn, sold the lot to Henry and Mary J. Bonnet in 1866 (BCDR Vol. H-1 1849:468, Vol. U-1

1866:186). It is not clear who constructed a house on the property, but by 1873 there is a structure present [as identified on the Koch's 1873 "Bird's Eye View of San Antonio" map, presented earlier as Figure 10]. In 1884, the Bonnets sold the western half of the lot to Adolph Scholz, which adjoined to his lot on the south (BCDRVol. 33 1884:65). The property passed to Mrs.

Edward Thompson, Jr., in 1906, and then to Marth M. Tong, who sold the property to A. B. Weakley in 1910 (BCDR Vol. 345 1910:431). A. B. and Susan S. Weakley sold the property to J. L. Langworthy of England in 1912 (BCDR Vol. 388 1918: 158).

Field Investigations

Lots A25 and 25 have now become the western portion of a parking lot area that extends to Lot 27. Mechanical testing consisted of a Gradall trench 2.7 meters wide and 30 meters in length. Hand testing consisted of two 1 x 2 meter units. Unit 2 ( 1 x 2 meters) exposed a small irregular trash deposit composed of burned, cut bone, and ceramic fragments.

Test Unit 3 ( 1 x 2 meters), excavated approximately seven meters east, was the extrapolated location of the residence constructed in the 1860's-1870's. As the actual house location was well beyond the new right-of-way limit, it was 
thought such a test unit might uncover evidences of a porch or householdrelated activities. No evidence of a stone or caliche/adobe foundation was noted. A moderate collection of mid-19th century metal, ceramic fragments and miscellaneous items were recovered in a cultural zone ca. 15 om thick and ca. $80 \mathrm{~m}$ below the surface. Upper soil deposits to a depth of more than $50 \mathrm{~cm}$ were severely disturbed by past recent construction activities. A summary of mechanical and hand excavations is presented below:

Table 3. Summary of Excavation Data, Lots A25, 25, NCB 165

$\underline{\text { Test Unit Type of Unit Dimensions }} \begin{aligned} & \text { Maximum Depth } \\ & \text { Below Surface }\end{aligned}$

\begin{tabular}{|c|c|c|c|c|c|}
\hline \multicolumn{6}{|c|}{ Lot A25 } \\
\hline & 1 & Gradall & ca. $2.7 \mathrm{x}$ & $99.45-98.45$ & 1) cut stone walkway (?), \\
\hline & & Trench & $\begin{array}{l}30 \text { meters } \\
\text { (extended }\end{array}$ & o Lot 26) & $\begin{array}{l}\text { see text 2) brick walkway, } \\
\text { disturbed (see text) }\end{array}$ \\
\hline & 2 & $\begin{array}{l}\text { Hand- } \\
\text { Excavated }\end{array}$ & $1 \times 2$ meters & $98.72-98.45$ & small trash pit \\
\hline & 3 & $\begin{array}{l}\text { Hand- } \\
\text { Excavated }\end{array}$ & $1 \times 2$ meters & $98.95-98.45$ & no features noted \\
\hline Lot & 25 & & & & \\
\hline & $\overline{4}$ & $\begin{array}{l}\text { Hand- } \\
\text { Excavated }\end{array}$ & $\begin{array}{l}2 \text { meter } \\
\text { square }\end{array}$ & $98.95-98.45$ & $\begin{array}{l}\text { excavated unit adjacent to } \\
\text { two small (recent) } \\
\text { concrete blocks }\end{array}$ \\
\hline
\end{tabular}

Two structural features were noted in Lot A25. An extensively disturbed brick walkway thought to be associated with an early 20 th century commercial structure, was uncovered ca. $20 \mathrm{~cm}$ below the surface (elev. 99.23') in the western portion of the lot. The walkway extends to the limits of the right-of-way and is otherwise buried in extremely disturbed modern rubble deposits just below the asphalt.

A second feature, first thought to be another walkway, was discovered at an elevation of 99.18 (27 am below the surface) along the mid-length of the lot 
(see Figures 22, 23). Consisting of sawed and chiseled limestone blocks, the feature extended across the width of the new right-of-way. The generally intact feature was 1.65 meters in width by 3.1 meters in length as uncovered, although it appears to extend both north and south for an unknown distance. The edges of the limestone feature are characterized by large flat blocks laid on end but angled inward toward the base of the feature. The blocks are unusually well constructed and their shallow depth below the surface may indicate a late 19 th or early 20 th century construction.

A third small feature, consisting of two parallel, narrow concrete blocks of relatively recent construction, was noted in Lot 25. A hand-excavated 2-meter square, excavated adjacent to the blocks to $100 \mathrm{~cm}$ below the surface (to basal caliche), did not recover any significant or diagnostic materials.

In summary, mechanical and hand testing has identified intact features and mid-19th and early 20th century cultural materials in portions of Lots A25 and 25. Although much of the subsurface has been extensively disturbed by modern commercial activities, some further work is recommended to more clearly describe and define the identified deposits (see Recommendations For Further Work)

Lots 26 and 27 Historical Background

In 1856, Giddings conveyed these lots to his brother, J. D. Giddings, but court settlement, in 1857, was awarded to Alex H. Rhodes and B. R. Sappington (BCDR P2:2). In 1866, Rhodes and Sappington sold the lots to H.W. Tong for $\$ 475$, it was after that date that the structure shown on the 1873 map was constructed (BCDR T2:748, Koch 1873). In 1903, it was the homestead of 


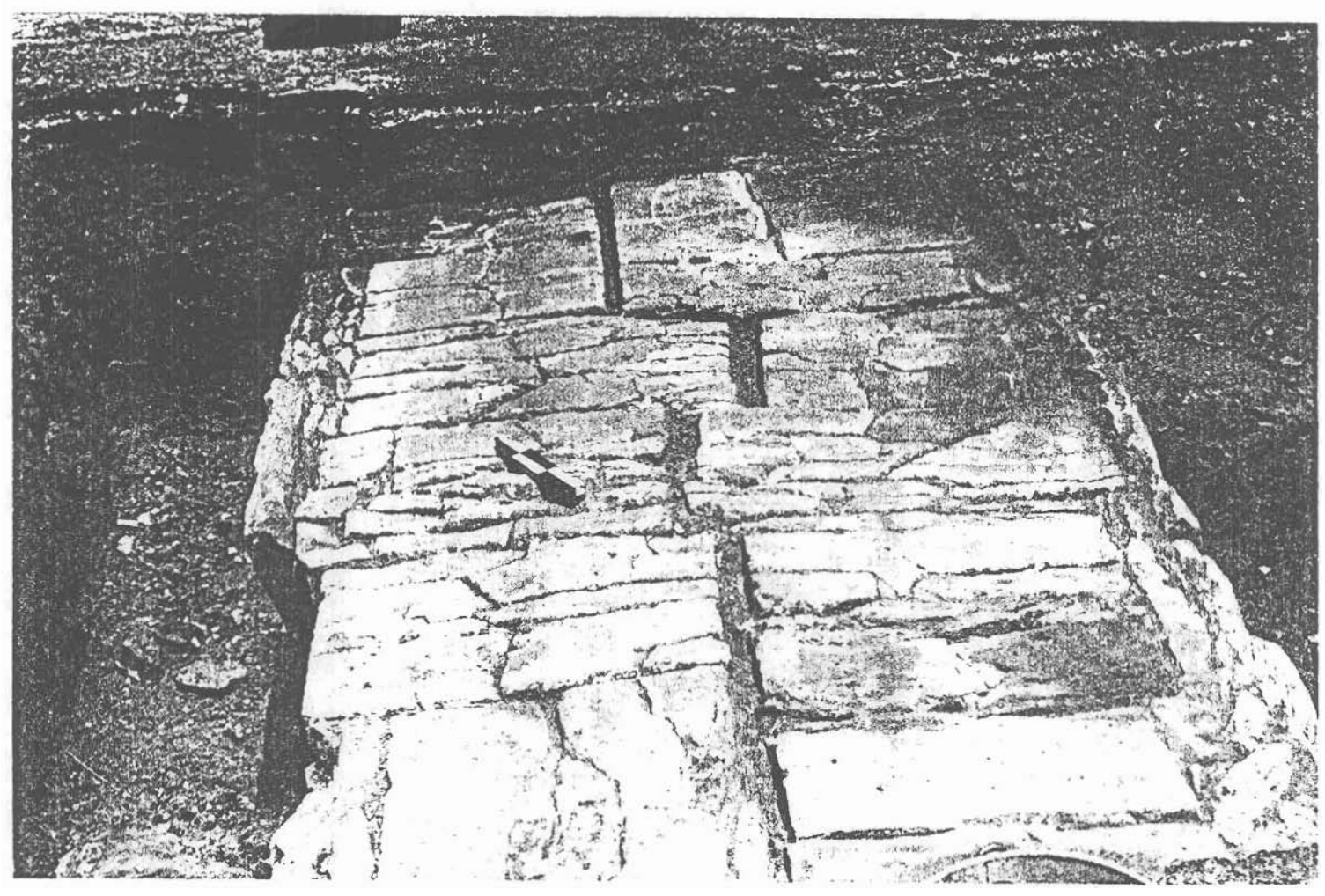

Fig. 22 Walkway (?) of large limestone blocks uncovered in Lot A25.

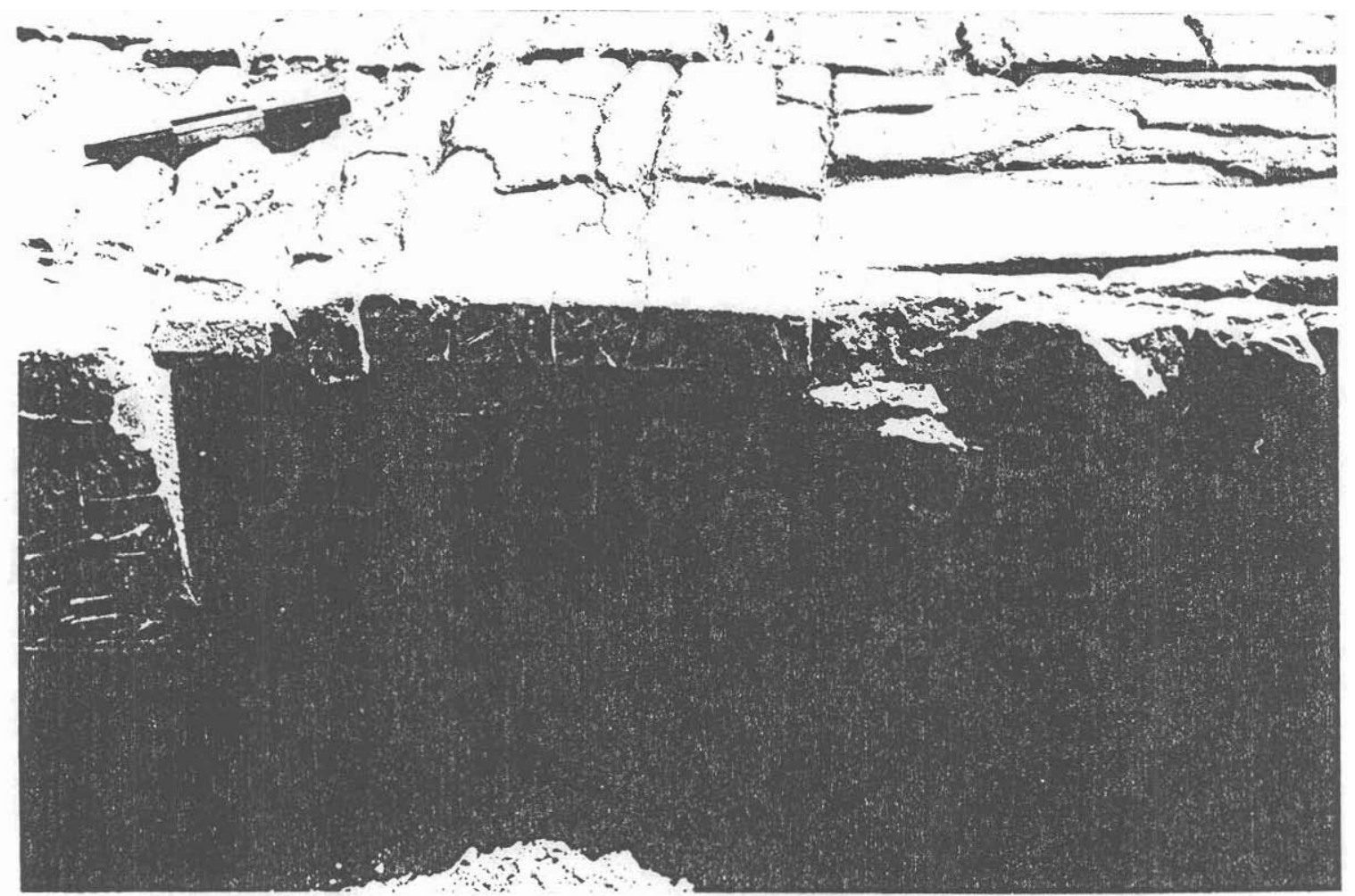

Fig. 23 Side view of limestone blocks showing profile. Note angle of stones laid at edge. 
H. Wash Tong, and in 1905, the residence of Mrs. M. M. Tong (City Directories 1903, 1905). However, in 1890, Horace and Martha Tong sold the property to J. H. and J. W. Moore and apparently rented from them. The Moore brothers transferred the property to J. D. Gillis in 1899 (BCDR65:359, 208:199). It was probably at this time that the small adobe or caliche block building was constructed on the easter portion of the lot that appears on the 1904 map (Sanborn 1904). In 1903, it was rented by Mike Saenz, and 1905 was vacant (City Directories 1903, 1905). In 1909, the widow Clara Gillis and her daughter, Ella, sold the property to Ed Seeling (BCDR 783:442). In 1914, he conveyed Lot 27 to the Colombian Building Association and the Woodman Circle (BCDR 388:158). By 1918, the Zizik Undertaking established occupied the first floor, and it later became the Targ and Dinner Wholesale Music Company. Lot 26 was purchased by J. L. Langworthy in 1912 (BCDR388:158). As noted with the previous lot, the city acquired them in 1985.

Field Investigations

Lots 26 and A27 are today covered in asphalt as part of a large parking lot that extends westward to Lot A25. Only the western portion of Lot 26 was examined by mechanical testing in the form of a three-meter long Gradall Trench (a continuation of Test Unit 1 of Lot 25, A25). The remainder of Lot 26 currently serves as the entrance/exit for the parking lot and it was considered impractical (and infeasible) to block this area for any length of time. Examination of this locale is scheduled during actual street construction when the parking lot entrance will be closed for some period. No features were noted or cultural materials collected from mechanical trenching (to basal caliche at a depth of one meter) in the western portion of Lot 26. 
Lot A27 was not tested because of an unusually thick concrete slab found below the asphalt and covering the entire lot. This slab could not be broken by mechanical pounding from the toothed bucket of the backhoe. The slab, relatively recent, is part of the foundation for the early 20 th century commercial structure noted by Cox (1987) in the Historical Background.

The entire right-of-way length of 1 ot B27 was tested by backhoe trenching to a depth of 1.75 meters (to basal caliche). No features or cultural materials were noted or collected. No structures identified from historical records (e.g. Sanborn Insurance maps or early maps) were identified during testing. This may be due in part to the depth of modern subsurface disturbance and the fact that several structures may have been located beyond the current right-of-way li mit.

It should be noted that the late 19 th century Tong family (identified from historical research) -- if they were of oriental extraction -- would offer an interesting cultural contrast to the Anglo-European development in this area. A more detailed archival review is necessary and recommended to identify the background of this family. To date, a preliminary review of the 1870 U.S. census records lists only a William and Virginia Tong (from Missouri and Texas, respectively) that does not match the individuals identified in the 1860's-1880's Bexar County Courthouse records in the Historical Background (see Figure 24). It should also be noted that the small caliche structure mentioned in the Historical Background as being constructed circa 1899 in Lot 27 also is shown in the 1896 Sanborn Insurance map of East San Antonio.

In summary, extensive modern disturbance and a lack of identified features or cultural deposits suggest that further mitigation (excluding testing of 
Páge No. $5 \not z\}$

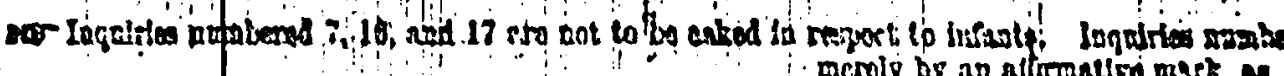
meniy by as altarenuleo mask, as

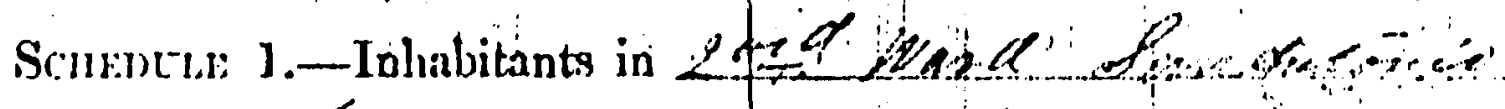
in the Ce

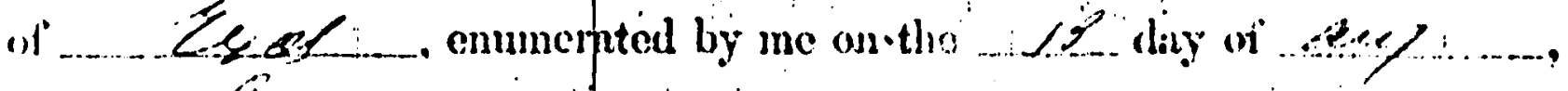

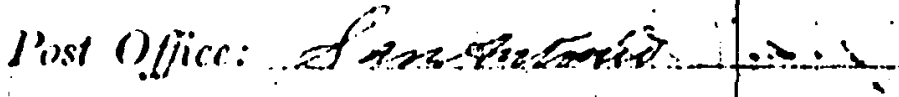

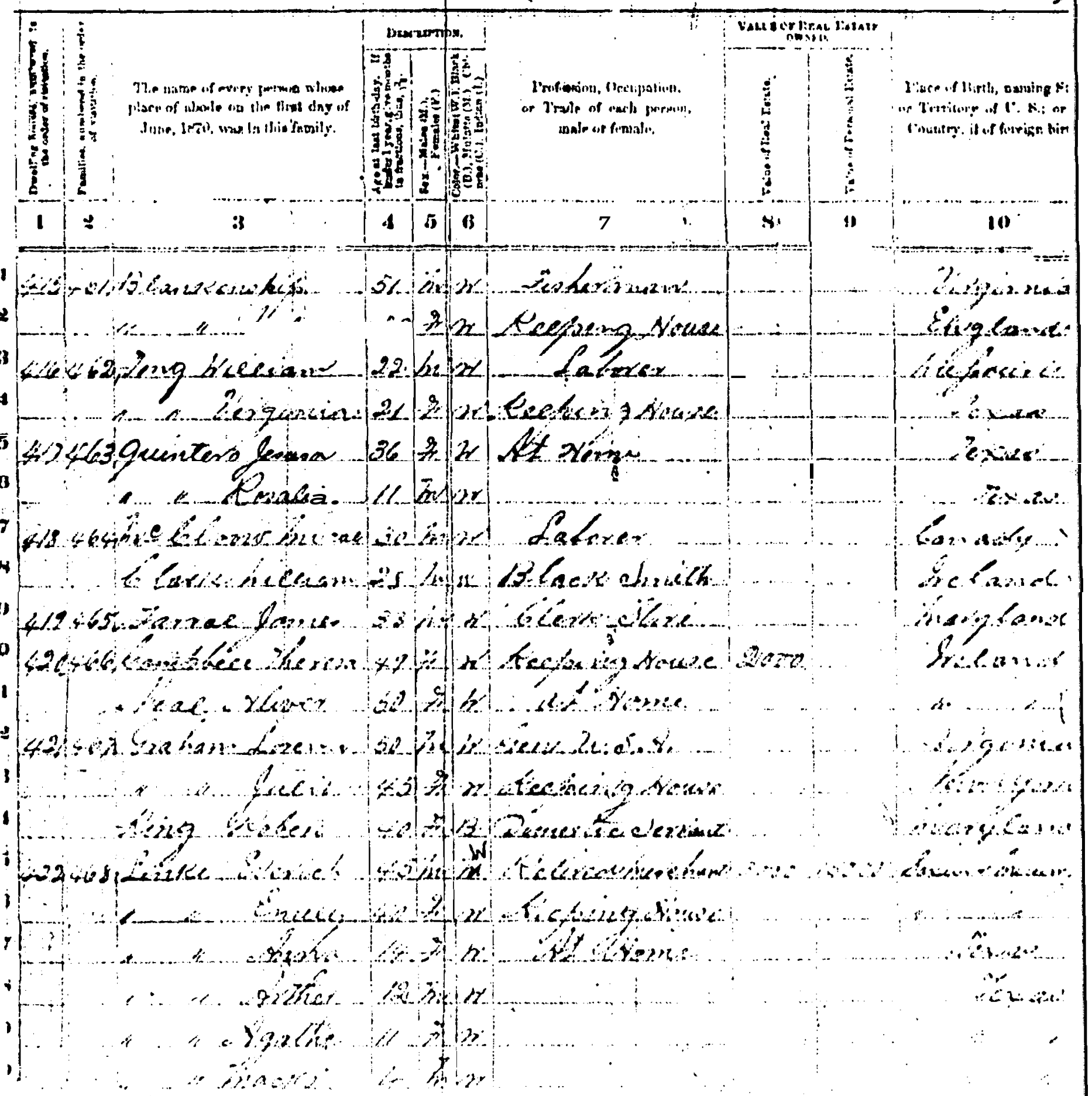

Fig. 24 Extract of 1870 census, San Antonio. Note Tong entries. 
uninvestigated portions) is not recommended at this time, given the available field work and historical research. It is recommended, however, that additional and more detailed archival review be initiated to determine the background of the Tong family and their relationship to the areal development at the turn of the century.

Lots 28 and 29 Historical Background

NCB 165, Lots 28 and 29

In 1851, Giddings conveyed these lots to Bernard Brady for \$200 (BCDR 12:409).

In $1873,1885,1888,1892$, and 1904 , the maps indicate that there are no structures on either lot (Koch 1873, Sanborn 1885-1904). In 1909 and 1913, there was a realignment of property between Thomas Conroy and the Maverick heirs in which the lots were transferred to Ed Seeling (BCDR 305:220, 328:380). The first indication of any structures appears in 1921 when the Dewey Auto Livery is listed as occuping the property (City Directory 1921). In 1934, the lots were occupied by the City Auto Parts Company (City Directory 1934). In 1986, the property was transferred to the city by Paul Seaborn of Santa Clara, California, as a parcel of lots 27, 28, 29, acquired by Clementine Seaborn (BCDR 717:315).

Field Investigations

The entire length of the new right-of-way area of lot 28 was tested mechanically by backhoe trenching to a depth of two meters. A small caliche layer ca. $10 \mathrm{~cm}$ thick and three meters in length was uncovered at the edge of the boundary between Lots 28 and 29. No artifacts or other materials were noted with this feature. The identification of this feature is dependent upon further field investigation as well as historical research. 
Although Cox (1987; extracted in Historical Summary) notes that the first indication of structures in these lots is circa 1921, the 1896 Sanborn Insurance map also shows a small structure, possibly a store, at the corner of E. Houston and Bowie Streets in 1896. No evidence of this structure has been found to date. Based on the evidence of intact subsurface deposits as well as the unestablished location of structures noted in historical documentation, some further work is recommended in these lots (see Recommendations for Further Work).

\section{Lot 14 Field Investigations}

No Historical Background is available to date for Lot 14 along Bowie Street. An archival review is currently in progress for this area. Lot 14 was examined by Gradall excavation, the mechanically excavated trench running the length of the lot (ca. 70'/21 meters). Approximately two meters wide, the depth varied from 210 to $120 \mathrm{~cm}$ below the surface. Deposits consisted of a modern upper soil disturbance over 50 m thick underlying undisturbed deposits of a very dark gray (10YR3/1) silty clay. Limestone rock and caliche with calcareous gravel nodules were encountered at varying depths of between onetwo meters. Very little cultural materials were collected from testing although three parallel limestone rock rubble foundations were exposed in the southern portion of the trench. The remains of the structure(s?) is thought to indicate the house shown on a series of 1890-1912 Sanborn Insurance maps of the area. There is some indication that this structure may be post-1870 (?) as it is not shown on Koch's 1873 map of the city.

Since much of the intact rubble foundation is located within the new right-ofway, it is poorly documented, and lacks an associated archival background, 
further work is recommended for this lot (see Recommendations For Further Work). In addition to the identified structures from historical documentation, it was thought there was a likelihood of encountering a lateral segment of the Acequia Madre in the area of Lot 14. This was based upon the original suerte boundaries of the land grant awarded to de la Zerda circa 1793-1797 (transcription and translation on file, Spanish Archives, Bexar County Courthouse, LGS. 717; see also Vol. III:229). The southern boundary of this suerte (illustrated in a survey map of 1849; see Figure 25) crosses Bowie Street just above the modern east-west boundary line that separates the modern northern and southern lots of $\mathrm{NCB}$ 165. Little trace of a former unlined ditch was found in this area although profiling and inspection of the trench walls did indicate a small disturbed fill area ca. 80-110 am below the surface running diagonally across the trench. This area, however, was filled with fragments of modern concrete and iron reinforcing bars. No early cultural materials were recovered from this area.

Given the extent of intact subsurface materials, the wide right-of-way area, and potential for further cultural deposits, some further work is recommended in Lot 14 (see Recommendations For Further Work).

\section{Lots 12 and 13 Historical Background}

(extracted from Cox, 1982:7)

In March 1851, Giddings sold the two lots at the corner of Crockett and Bowie Streets to Jane Johnson (BCDR Vol. I2 1851:408). The following year Jane and her husband, Thomas, sold the lots to Bernard Brady at no increase in price, indicating that no improvements had been made (BCDR Vol. K2 1852:44). Shortly 


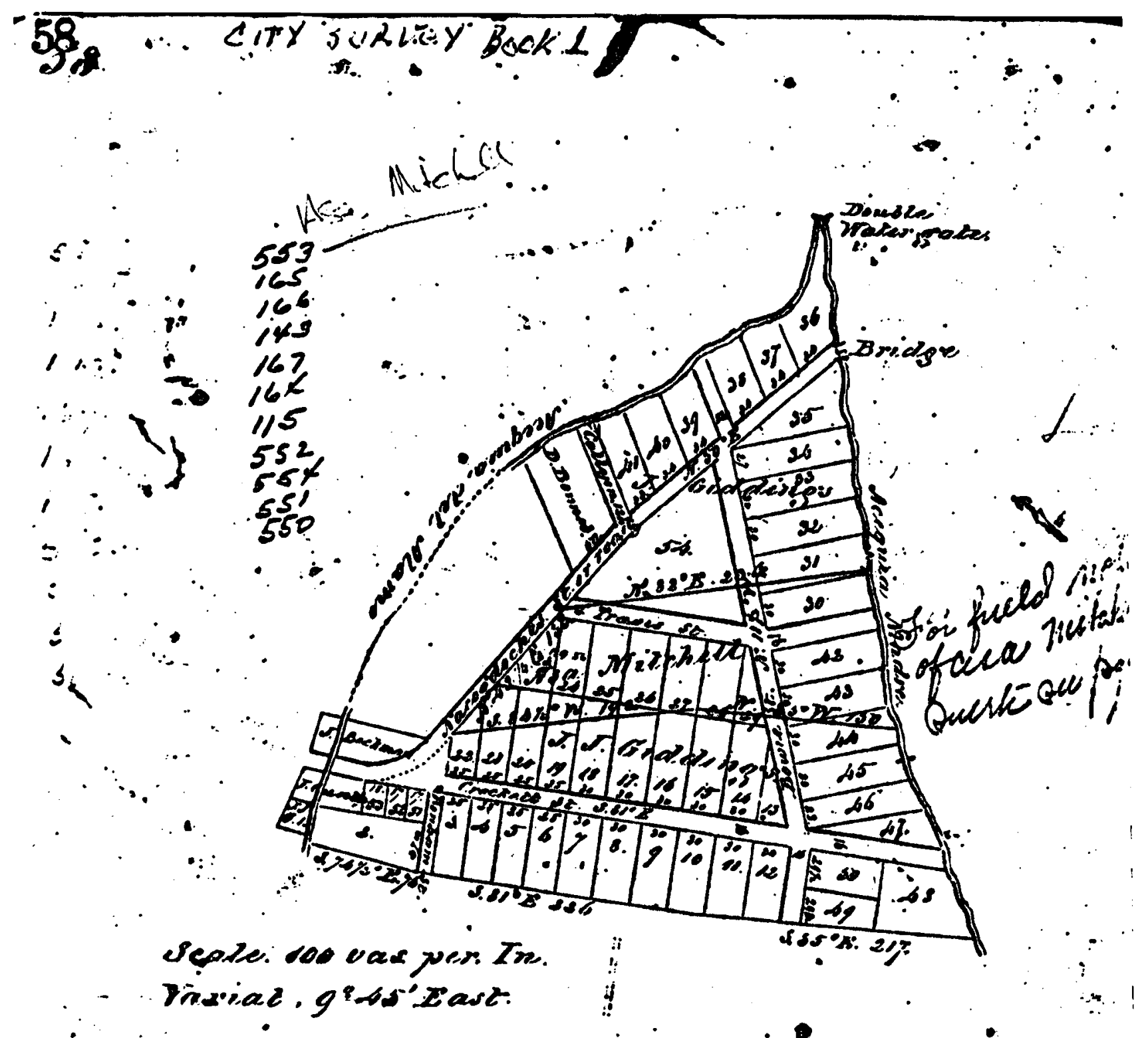

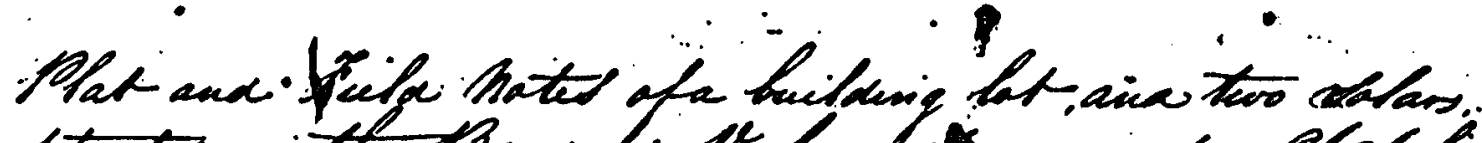

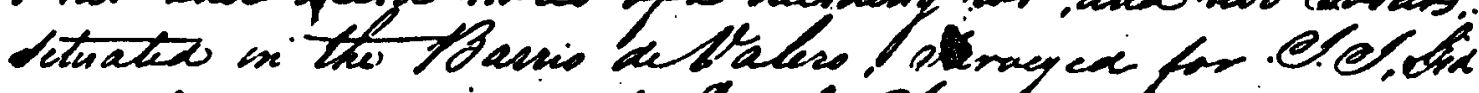

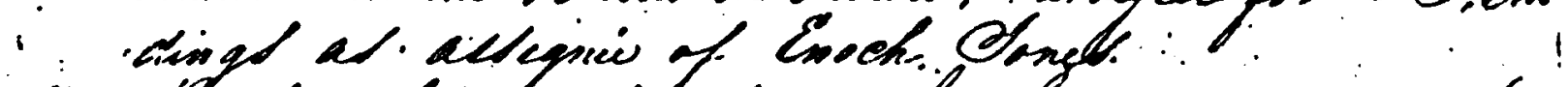

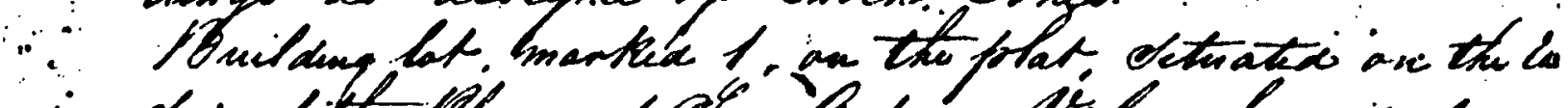

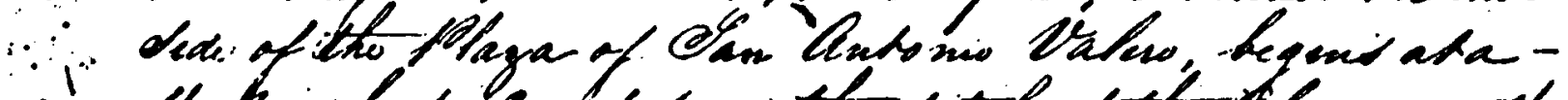

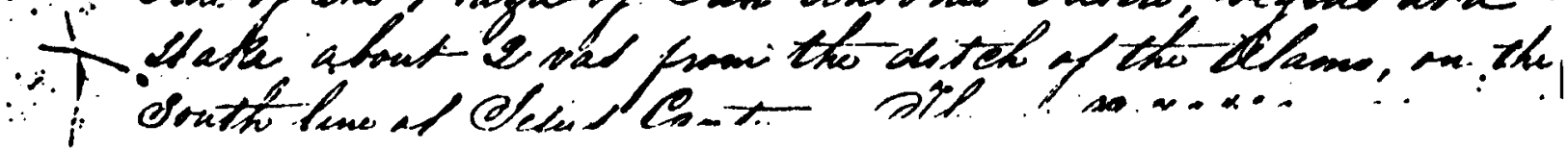

Fig. 25 Extract of Field Surveyor's Notes for Study Area, circa 1849. 
after that date, Brady apparently constructed a house upon the lots, for later transfers of the property refer to the lots as the Brady Homestead. At any rate, there was definitely a house on the lots by 1873 (as notated on Koch's 1873 map of San Antonio). Bernard and Susan Brady transferred the property to Ellen (Hopkins) Davis who in turn sold it, through her attorney, Bryan Callahaghan, to Luis Huth in August 1882 (BCDRVol. 23 1883:550). Huth was the owner of L. Huth and Sons Hardware located on the southwest corner of Market and Cochran Streets. By 1909, the house was occupied by Mrs. Leona Huth, apparently widowed (Appler 1909). The house stood until 1913 when the Karges Building, present structure on the lots, was constructed. [Author's note: the Karges Building has been demolished since Cox's 1982 work].

Field Investigations

Eight mechanically excavated trenches and one hand-excavated 2-meter square made up the field work in Lots 12 and 13 (see Figure 26). The southern half of Lot 12 where the 19 th century residence would have stood, was contained over three meters of collapsed modern building rubble that had been pushed into the building's basement (see Figures 27, 28). № intact deposits are left in this portion of-the lot. The northern section was found to contain bone and trash deposits related to the late 19th century dwelling. An 18801890's trash pit ca. 3 meters in diameter was recognized during trenching. The deposit was located 110-190 om below the surface (98.43-97.63).

A hand-excavated 2-meter square was. established over the ash-layered pit and subsequently excavated. A large number of late 19 th century artifacts were recovered including several forms and varieties of ceramics, personal items, and household/kitchen items. Glassware included several complete bottle 


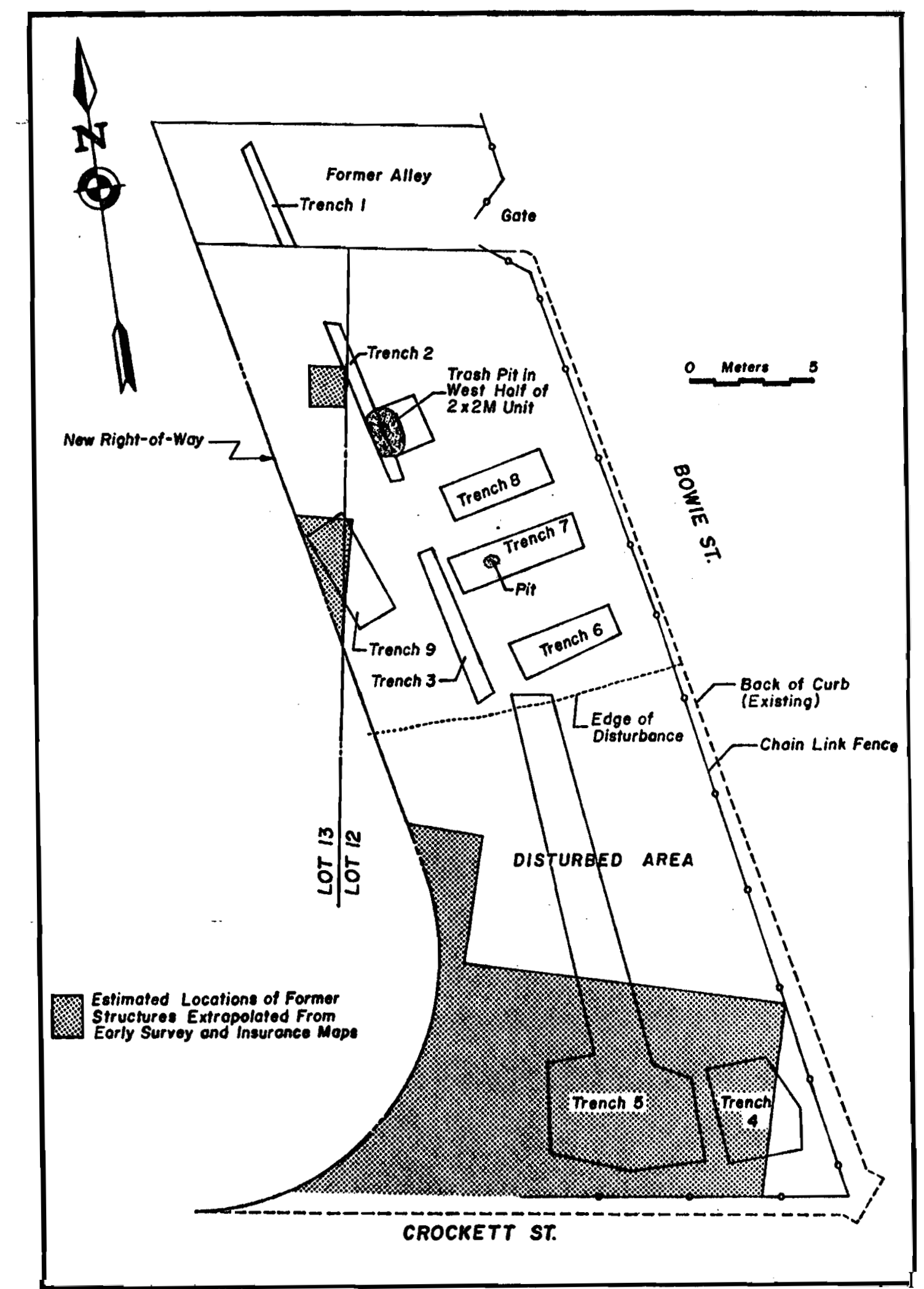

Fig. 26 Plan map of Testing Operations, Lots 12/13. 


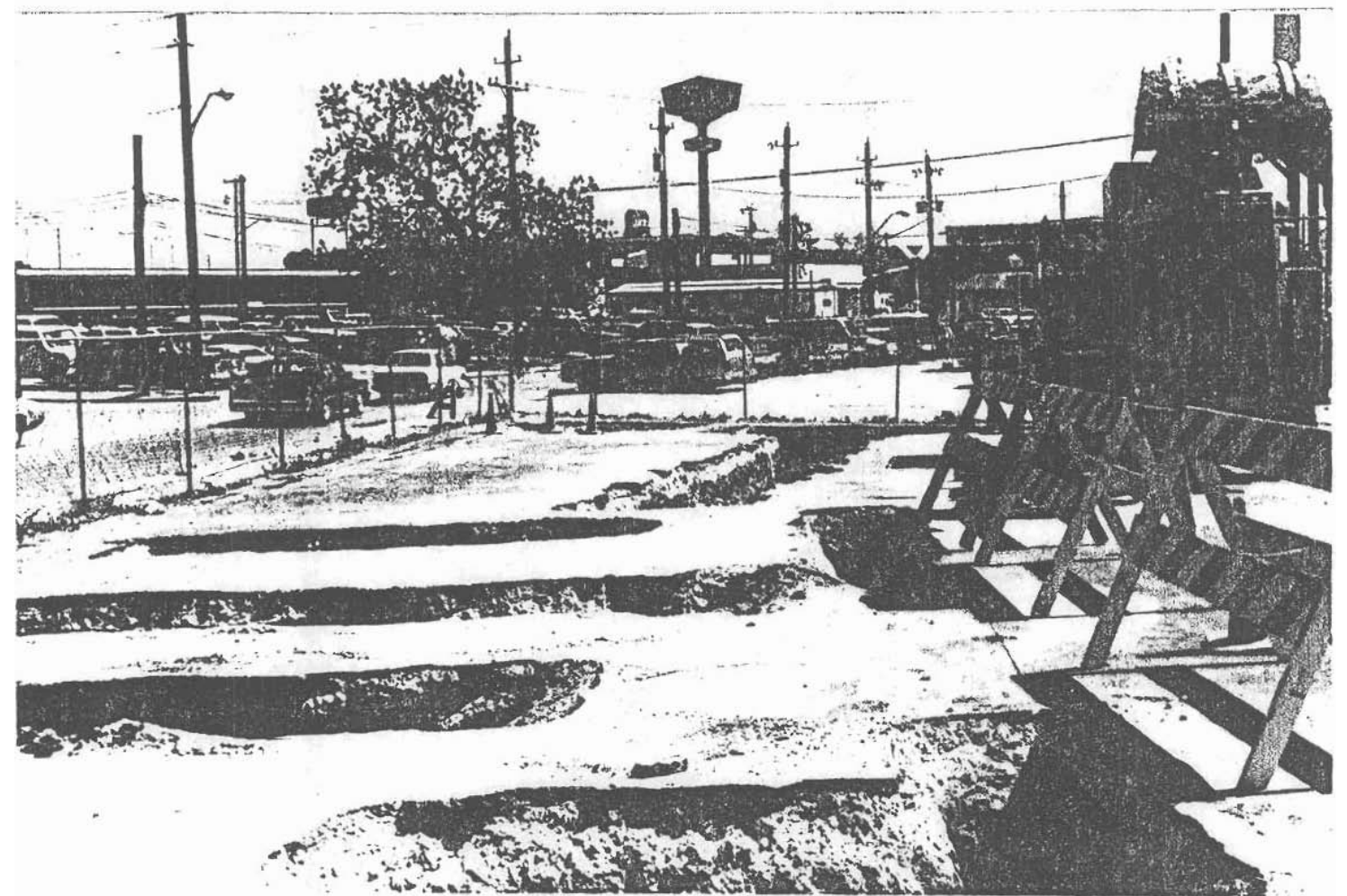

Fig. 27 View of hand and mechanical testing in Lots 12 and 13, looking south. Extensively disturbed area is located around trench in background. Intact cultural deposits extend from foreground to last trench running east-west.

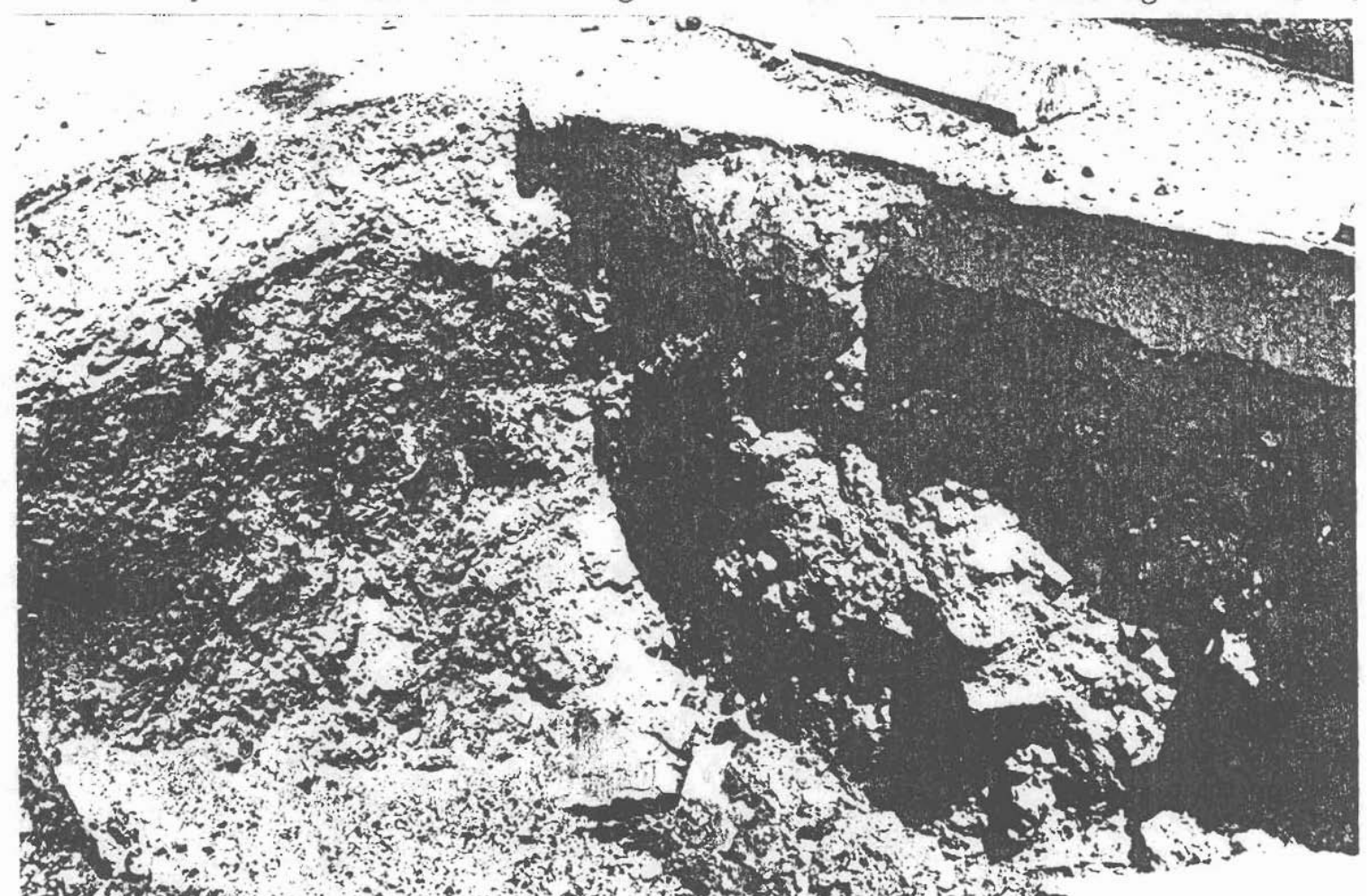

Fig. 28 Former basement of Karges Building filled with collapsed building rubble (ca. three vertical meters of modern refuse), in southern half of Lot 12 . 


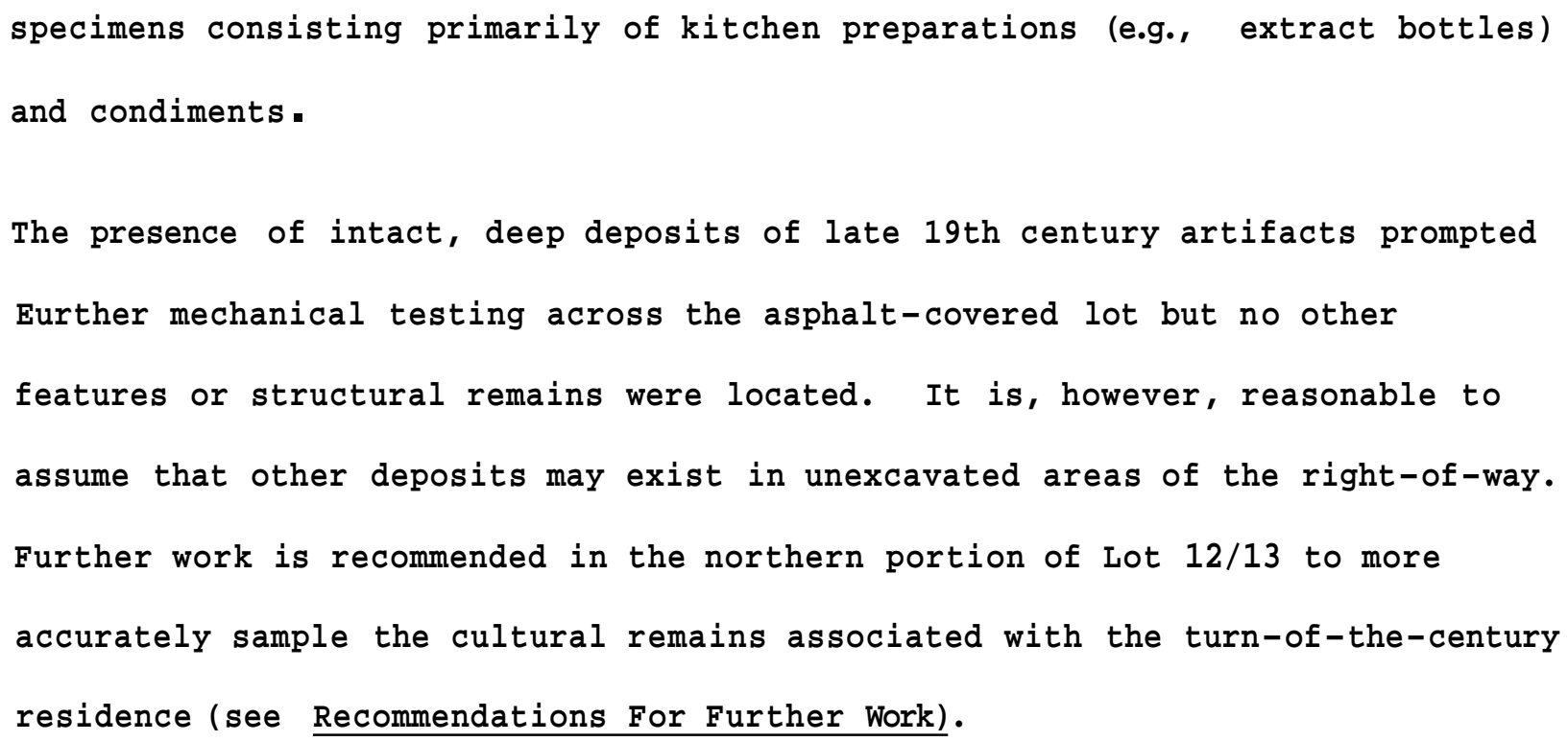


RESEARCH DESIGN AND METHODOLOGY

Research Approach to Further Work

Three major perspectives of further work are formulated: (1) a spatial; (2) a conceptual and; (3) a temporal framework. These perspectives, broad in scope, and patterned after the research concepts of Cressey and Stephens (in Dickens 1982:44), offer a flexible approach to future field and archival research.

The spatial framework is seen as the determination of urban group material patterns and interpretations based on the identity and locations of ethnic status groups. It is thought such a framework would best be approached through three levels of investigation: (1) a site, or lot, specific context; (2) an intra-block perspective; and, (3) an inter-block interpretation of changes and similarities in patterns of development. The past work of CAR-UTSA is throught to be potentially useful in this last area as the previous work was not only block-wide in scope but also adjacent to the current project area.

The inter-block interpretative approach is directly related to the conceptual framework of future studies. Following the identification of inter-block socio-economic patterns, identifications may be made of broader culturalhistorical trends and influences of the city's development and evolution. An example of this approach would be the recognition of changing economic and social patterns at the end of the 19th century. Significant population increases from 1870 to 1880 may be related to San Antonio's prosperous status as a south Texas cattle center. The population increase, however, included an influx of middle-class to affluent Anglo-Europeans, many of whom developed 
varied merchant and business interests, and in the process, formed a stable and ever-increasing commercial aspect to the developing city's economy. It is postulated that such a transition from agri-business to a varied base of incipient commercialism at the end of the 19 th century did much to soften the impact of an otherwise collapsing cattle market across the region at the same period. A research question posed by this perspective could include an assessment of the similarities and difference of urban cultural-historical development to other South Texas cities during similar time periods.

The third and final perspective, the temporal framework, would be utilized to identify changes in land use, settlement patterns, and material/artifact distributions, This has been stated appropriately and succinctly by Cressey and Stephens (in Dickens, 1982:50): "do settlement and artifact patterns as expressions of social and spatial organization relate to economictechnological changes."

Special emphasis will be placed upon the patterns of material refuse throughout the study area and across the different lot areas. These will be identified to suggest similarities and differences of artifact and faunal (burned, discarded items. in trash pits) assemblages. Methods of trash disposal have been found to be particularly useful during such interpretations (see Deagan, in Schuyler 1982:198-200) and care will be given not only to the recovery of such information but also to related patterns of human waste disposal and privies. It has been pointed out that only through such detailed documentations of material patterns can the researcher understand the broader relationships of ownership, use, and discard of artifactual remains (see also Graffam, in Schuyler 1982:217). 
Major intra-city comparative sources for such interpretive studies (in the San Antonio area) include unpublished data on file at the CAR-UTSA for the Las Tiendas archaeological-historical investigations, John W. Clark Jr.'s (1984) report on an early 20th-century San Antonio dump, the recent LaVillita excavations (Labadie 1986), and the earlier Arcinega Street excavations (Katz 1978). Pertinent background studies of the Mission San Antonio de Valero (The Alamo), because of its proximity to the study area, will also be reviewed and synthesized, as they compare to stratigraphy, cultural deposits, and features [e.g. Greer, 1967, Eaton, 1980, and Tunnel in working papers report for Houston-Bowie (Feb. 1987)].

Objectives and Methods of Investigation

The objectives of mitigation are numerous because of the nature of the resources to be mitigated. The resource considered here consists of a long span of 19 th and early 20 th century occupational activities as well as more recent commercial developments. A significant potential also exists for 18th century Spanish Colonial remains. Historic sources for this area consists of a variety of documentation including deed and tax records, census data, marriage and baptismal records, eye-witness accounts of events in the area, utility records, photographs, and more. Individual lots often contain discrete features, a variety of artifacts, and horizontal relationships that provide much cultural data.

Among the objectives of mitigation of the site are the following:

1. To provide a chain of deed records of sales and purchases for the properties involved.

2. To provide an historical background including as much biographical and 
genealogical information as possible.

3. To associate the site with contemporary study units as defined in Brown et al. (1982).

4. To collect informant data on the cultural life within this portion of San Antonio.

5. To define spatial and cultural relationships for lots involved in the project area.

6. To discuss the architecture of the lots.

7. To define the horizontal or spatial relationships within the lots, compared to the others in the area and compared to sites in other areas where appropriate studies have been conducted.

8. To define patterns of artifact type frequencies for individual lots and compare the results to other sites.

9. To discuss the market system utilized by the site occupants with regard to artifact sources, both local and national.

10. To examine certain artifact categories with regard to their expression of relative wealth or status.

11. To discuss family and demographic patterns in relation to other areas of 19 th and early 20th century America.

12. To discuss subsistence as reflected by artifacts and organic materials at the sites.

In order to realize these objectives, a variety of methods will be utilized. At the present time a moderate amount of archival data has been collected including deed records; historical eye-witness accounts, origins of settlers, informant data, and genealogical information. Pursuit of documentary or archival information will continue in order to provide adequate information to 
achieve Objectives 1 through 5. This will involve work at the Barker Texas History Center, State Archives, State Library, County Courthouse, the Daughters of the Republic Research Library, the Alamo, oral history interviews, and other efforts.

To achieve Objective 6, features will be exposed, photographed, drawn, and compared to similar features still standing at other sites, visible in historic photographs, and otherwise documented, in order to develop as complete architectural reconstruction as possible. Objective 7 will be achieved through the gridding of the site and excavation or surface collection of the material. This procedure will be done via the establishment of grids and the passing of excavated material through 0.25 in. hardware cloth. The deposits may be more than 3 meters in depth and stratified, so vertical level increments will be utilized in the form of arbitrary 10-cm levels or by cultural stratification of deposits, as appropriate.

Objective 8 can be achieved by cataloging artifacts in pre-established categories (South 1977), quantifying them, and comparing them to artifact patterns defined in the existing literature. The actualization of Objective 9 involves the identification of place of manufacture of as manyartifacts as possible. This procedure is relatively easy for ceramics and bottles. Many of these will represent national brands, while some will pertain to local distributors. Again, this information can be quantified and compared to other sites.

Objective 10 is likewise relatively easy to deal with. Certain kinds of ceramics, for example, are known to have been less expensive than others; the same is true for liquors, art glass, and other items in general use. The pre- 
sence/ absence of certain types of artifacts, as well as tax records, should provide the requisite data. There have been studies of family relationships and demography (Hareven and Vinovskis 1978) which will provide comparative data to which information generated by this project may be compared. Finally, subsistence evidence such as bottles, cans, and so forth, and actual food remains such as fruit pits, bones, egg shells, seafood shells, and so forth, will be studied. Bones can provide information on what animals were utilized, how they were cut, relative expense of cuts, and preferences of individual families for example.

In summary, the objectives of mitigation herein listed have, as their common goal. the development of information on (1) the level of integration of the inhabitants of the area into national and local markets, (2) material manifestations of ethnicity and social status, and (3) horizontal patterning of artifacts and the functional pattern of artifacts as a manifestation of culture. Other goals include the development of a local history of the project area, encompassing land transactions, patterns of inheritance, family relationship patterns, demography of the area, and subsistence. 


\section{RECOMMENDATIONS FOR FURTHER WORK}

The following presents a summary of recommendations for further work for specific site/lot areas as well as a brief discussion of other project considerations.

\section{Lot-Specific Recommendations}

\section{Lots $23 / 24$}

Due to the paucity of collected materials associated with the structural features in Lots 23 and 24, further testing in as yet uninvestigated portions of these lots is recommended. The actual portions are modest in size (ca. 5-meters square, each) however, they would have once consisted of both the inner and outer areas of the original house structure. An enlarged sampling collection from Lot $23 / 24$ would contribute significantly not only toward a more accurate appraisal of lot deposits but could also be used toward inter/intra-block comparisons to other similar, structural remains, for example, those located in Lots 14 and 29.

\section{Lot A25}

Like the previous lots, Lot A25 contains a distinctive structural feature, thought to be a limestone walkway, but which is poorly defined functionally, chronologically, or culturally. The immediate area of this feature could benefit from further testing to define the feature's spatial and functional context. This data, again, could be utilized for intra-block cultural comparisons. Additionally, further specific archival research is also recommended for the Tong family, to include assessments of their nationality and cultural impact to the study area. 
Lot $28 / 29$

A small caliche structural feature was identified in Lot 28 that has not been documented through historical record. Additionally, the small structure noted on the corner of Houston and Bowie Streets circa 1896 has not yet been

located. Given the proposed testing of previous lots in this area, it is recommended hand-excavations utilizing a series of contiguous 2-meter squares and standard archaeological techniques be employed here for both a more detailed lot-specific assessment but also intra-block comparisons. Units will be oriented to a site grid as well as to specific features identified during excavations.

Lot 14

The existance of intact rubble stone foundations and the lack of supportive historical documentation suggests this area could benefit by further work. Hand excavations to expose the foundations within the right-of-way as well as further archival research is recommended in Lot 14

Lot $12 / 13$

The existance of deeply buried cultural deposits has been confirmed by previous testing. Although ca. $50 \%$ of the lot area has been severly damaged by past commercial activities, additional materials relating to the late 19 th century residence may exist in the northern portion of the site. Additional$1 y$, it is reasonable to assume there may also be as yet undiscovered remains of outbuildings, wells and/or cisterns in the lot. The sampling of such features and materials would do much to more accurately define the character and lifeways of this turn-of-the-century family. Block excavations utilizing contiguous 1-meter squares, similar to those recommended for the adjacent Lot 14 , is suggested for Lot 12 . 
(A) Further archival/historical review of New City Block 165 is recommended to include all impacted lots. To date, little specific data is available for land ownerships prior to 1836-1840 although several de la Zerdas' (also spelled Cerda) are noted in the historical record. The families associated with all identified structures are poorly known (or only most generally described). Little information is available as yet, on the post-1900 commercial development of Houston and Bowie Streets and this constitutes a significant gap in the recognized socio-economic development of the project area. Lastly, and most importantly, the data accumulated to date as well as research recommended should be interpreted from intra- a swell as inner-block patterns of urban development. This should include direct assessments and comparisons to date from previous work such as the UTSA Las Tiendas studies currently under way and other past downtown historical investigations. It is anticipated such archival/historical overview would include oral history interviews with family descendants, former property owners, and informants as appropriate as well as deed, tax, census, baptismal and death records reviews. Further archival reviews are recommended at such specific sources (in addition to those previously listed) as the Spanish Archives, the University of Texas at Austin and the Spanish Archives of the General Land Office, Austin.

(B) The scheduling, equipment and man-power for additional, recommended work should be compatible and concurrent with construction activities and the overall street completion. The limited time and work-days available should be recognized during planning of additional studies.

(C) Systematic on-site monitoring of construction activities in the existing right-of-way is projected (as originally recommended) during future construc- 
tion phases. Such work would be initiated only during periods of uncovering existing right-of-way areas.

(D) Although a relatively extensive amount of previous historical/archaeological work beginning in the 1960's has been accomplished in downtown San Antonio, little to no subsurface correlations of natural stratigraphy, depositions of cultural zones, or even soil type descriptions have been made. It is recommended that such work, integral to the present work, be expanded to review stratigraphic data and offer systematic, quantifiable assessments of inter-block stratigraphy and soils description. Such work, modest in scope, would offer significant practical benefit to not only interpretations of stratigraphy during project analysis but to future'researchers as well.

\section{SUMMARY}

Background archival research supplemented by a program of systematic testing indicates that portions of Houston and Bowie Streets, San Antonio, Texas, contain significant historical features and deposits related to varying periods in the-development of the city. Recommendations for further work regarding these cultural resources prior to potential negative impacts have been presented in some detail. The documentation and investigation of these remnants of 19th and early 20th century San Antonio are thought to offer significant contributions to a future understanding of the historical development of the city. 
$\begin{array}{cl}\text { Bexar County Deed Records (BCDR) } & \text { Ren } \\ 1854-1912 & \text { Various entries, on file, Bexar County Courthouse, San } \\ & \text { Antonio, Texas }\end{array}$

Chabot, F.

1937

With the Makers of San Antonio, privately published, San Antonio

City Directories 1877-1934

City of San Antonio", on file Center for Archaeological Research, The University of Texas at San Antonio (CAR-UTSA), and Library of the Daughters of the Republic of Texas (DRT), San Antonio.

Clark, John W., Jr. 1984

An Early Twentieth Century Dump in North San Antonio, Bexar County, Texas. Texas State Department of Highways and Public Transportation (SDHPT), Publications in Archaeology Report No. 26, Austin.

Cox, I. Waynne 1987

An Archival Analysis of Seven Lots on Houston Street, New City Block 165, San Antonio, Texas. CAR-UTSA.

1982

Preliminary Cultural Resources Study of the Houston and Crockett Streets Parking Lots, San Antonio, Texas.

CAR-UTSA.

Cressey, Pamela and John F. Stephens

1984

The City-Site Approach to Urban Archaeology. In: Archaeology of Urban America: The Search for Pattern and Process, pp. 41-62. Edited by Roy S. Dickens, Jr., Academic Press, New York.

de la Pena, Jose Enrique 1975

With Santa Anna in Texas, A Personal Narrative of the Revolution. Translated and edited by Carmen Perry. Texas A \& M University Press, College Station.

Deagan, Kathleen 1982

\section{Graf fam , Gary} 1982
St. Augustine: First Urban Enclave in the United States. North American Archaeologist, edited by Robert L. Schuyler, Vol. 3:3:183-206.

The Use of Pattern in Student Material Culture: A Preliminary Report From Harvard Yard. North American Archaeologist, edited by Robert L. Schuyler, Vol. 3:3: 207-224. 
Habig, M. A.

1977

Hareven, Tamora K., and Maris A. Vinovskis (Editors)

1978

Illustrations

Katz, Paul R. 1978 circa $1720-$ 1729

1764

1836

1836

1837

1873

$1885-1912$

Markey, Betty $\mathbf{J}$. 1981

On file, D8-E, SDHPT, Austin. Survey Report No. 61. History Center, Austin. Center, Austin. Antonio. Library, The Alamo, San Antonio. Bexar County Courthouse. History Center, Austin.
The Alamo Mission, Franciscan Herald press, Chicago.

Family and Population in Nineteenth-Century America. Princeton University Press, Princeton.

Vicinity of Commerce and Bowie or Bonham Streets,

P. Pinckney (Paintings in Texas: The 19th century).

Vicinity of Crockett and Bonham Streets, circa 1860. 19th century lithograph by Herman Lungkwitz (in Cities In

Stone). On file, D-8E, SDHPT, Austin.

Archaeological and Historical Investigations In the Acinega Street Area, Downtown San Antonio. CAR-USTA Archaeological

Villa de San Antonio de Casafuerta, by the Marquis de Aguayo. Original in the Archivo General y Publica de la Nacion, Mexico, D.F. Extracted from Maridith Schuetz's Historic Background of the Mission San Antonio de Valero, State Building Archaeological Program, Report No. 1, Austin.

Mapa del Presidio De San Antonio De Bexar. Drawing from Menchaca. Extracted from M. Schuetz, 1966, State Building Archaeological Program, Report No. 1, Austin.

Labastida's Map of the Alamo. On file, Barker Texas

The Siege and Taking of the Alamo. Text and Map by General Miguel A. Sanchez Lamego. On file, Barker Texas History

Rullmann's Map of San Antonio. On file, Daughters of the Republic of Texas Research Library, The Alamo, San

"Birds Eye View of San Antonio', by F. Koch. On file DRT

Street Map of San Antonio. On file, Spanish Archives,

Sanborn's Insurance Maps, San Antonio, Texas, Barker Texas

Preliminary Cultural Resource Assessment For The Las Tiendas Del Rio Project. CAR-UTSA. 
South, Stanley 1977
Method and Theory in Historical Archaeology. Academic Press, New York.

Schuetz, Mardith K. 19661

Historic Background of the Mission San Antonio de Valero. State Building Commission Archaeological Program, Report No. 1, Austin.

Steely, James $\mathrm{W}$. 1984

A Catalog of Texas Properties In the National Register of Historic Places. Texas Historical Commission, Austin.

Williams, Amelia 1933

A Critical Study of the Siege of the Alamo and of the Personnel of its Defenders. Southwestern Historical Quarterly, Texas State Historical Association, Vol. XXXVI, No. 4.

REFERENCES CONSULTED

Archaeological Background Data:

Fox, Anne, Feris Bass, Jr., and Thomas R. Hester

1976 The Archaeologyand History of Alamo Plaza. CAR-UTSA

Archaeological Survey Report No. 16

Katz, Susana R. 1985

Test Excavation of a Section of the Old Alamo Acequia. The PRIAM Company, San Antonio.

Katz, Paul R. 1978

Archaeological and Historical Investigations In The Arciniega Street Area, Downtown San Antonio, Texas. CAR-UTSA Archaeological Survey Report No. 61.

Labadie, Joseph H., assembler 1986

LaVillita Earthwork (41BX677), San Antonio, Texas. A Preliminary Report of Investigation ofMexican Siege Works at the Battle of the Alamo. CAR-UTSA, Archaeological Survey Report No. 159.

Subsurface Stratigraphy and Soil Profiles in the Alamo Plaza Area (And proximity):

Eaton, Jack D. 1980

Excavations at the Alamo Shrine (Mission San Antonio de Valero). CAR-UTSA, Special Report 10.

Greer, John W. 1967

A Description of the Stratigraphy, Features, and Artifacts From An Archaeological Excavation at the Alamo. State Building Commission, Report No. 3, Austin. 
Tunnell, Curtis 1966

A Description of Enameled Earthenware From An Archaeological Excavation At Mission San Antonio De Valero. State Building Commission Archaeological Program, Report, No. 2 . 